IV. On the Muscular Atlachment of the Animal to its Shell in some Fossil Cephalopoda (Ammonoidea). By G. C. Crick, F.G.S., F.Z.S., of the British Museum (Natural History). (Communicated by the PrestuenT.)

(Plates 17-20.)

Read Srd February, 1898.

INDICATIONS of the muscular attachment of the animal to its shell have been tigured in not a few Nautiloids, but comparatively few Ammonoids have been recorded in which what has been believed to be the remains of this attachment has been figured and described. Of these the best known are Oppel's figures of three examples of Ammonites steraspis * from the Lithographic Stone of Bavaria, published in 1863, in which the body-chamber of each is shown to be traversed by a fine curved line, the relation of which to the animal was not, however, indicated by the author.

In 1870, Trautschold $\dagger$ figured a specimen of Ammonites bicurnatus, exhibiting what he considered to be the impression of the muscular attachment of the animal, but this figure differs considerably from Oppel's figures.

In the following year, Dr. W. Waagen $\ddagger$ published his important paper, "Ueber die Ansatzstelle der IIaftmuskeln beim Nautilus und Ammonoiden," in which he expressed his opinion that the "shell-muscle" in the Ammonoidea was attached to the inner (umbilical) portion of the lateral area of the whorl. He believed the curved line figured by Oppel on the body-chamber of Ammonites steraspis to be a trace of the "annulus," and probably also of the shell-muscle, and, reproducing one of Oppel's figures, he completed by a dotted line what he considered to be the form of the shellmuscle. This interpretation of Oppel's figures has been accepted by most authors.

In 1879, Eck $\S$ figured and described a small septate fragment of Ceratites semipartitus from the Upper Muschelkalk of Schwicberdingen, near Stuttgart, which he thought showed not only the appearance of the surface of the mantle (the so-called "epidermids"), but also the impression of the annulus. The specimen was merely an internal cast of five chambers, and on the surface of the cast of each chamber there was a depressed zone with a finely-pitted surface, occupying on the siphonal region the middle two-thirds, and becoming much narrower on the side of the whorl; in two of the chambers a groove was also present on the antisiphonal area.

* Pal. Mittheil. p. 251, pl. Ixix. figs. 1, 2, \& 6 (1803).

+ Bull. Soc. Nat. Moscou, rol. xliii. pp. 301-306 (1870).

‡ Palæontographica, vol. xvii. pp. 185-210, pls. xxxix. \& xl. (1871).

$\S$ Zeitschr. deutsch. geol. Gesell. vol. xxxi. p. 276, pl. iv. figs. $5 \alpha-d(1879)$.

SECOND SERIES.-ZOOLOGY, VOL. VIr. 
In his large works on the 'Triassic Cephalopoda, Dr. E. von Mojsisovics* has figured several species of Ammonoids learing on the internal cast of their body-chamber a groove or grooves (extending in some examples from the umbilicus on one side, over the periphery, to the umbilicus on the other side), which he considered to be the impression of the homologue of the muscular attachment of the recent Nautilus.

Dr. O. Jaekel $\dagger$, in 1889, figured a Ceratite from the Trias of Rüdersdorf, near Berlin, hearing a groove precisely similitr to those figured by Dr. E. von Mojsisovics, and although he doulnted this indicating the position of the homologue of the annulus and of the shell-muscle in the recent Nautilus, he was unable to give any explanation of its nature. After all examination of Oppel's original specimen, this author says the line which Oppel figured and which has been regarded as indicating the position of the anterior houndary of the anmulus and of the shell-muscle can scarcely be followed with certainty, and he is inclined to doubt the correctness of the interpretation.

In his "Vorläufige Mittheilıng über die Organisation der Ammoniten ’ †, Dr. Steinmann evidently does not agree with Dr. Waagen's interpretation of Oppel's specimens (although he seems to make no special reference to them), a fact which is clearly brought out in the 'Elemente der Paläontologie' (1890) by himself' and Döderlein, where (p. 351, fig. 402) one of Oppel's figure's (Pal. Mittheil. pl. Ixix. fig. 2) is reproduced, and the curved line on the body-chamber completed in the manner suggested by Waagen, but in the explanation of the figuro this line is thus described: "(?) vordere Grenze des Haftbandes."

At the meeting of the Geological Society of London which was held on March 25th, 1891, a communication was read from Mr. S. S. Buckman, entitled " Notes on Nautili and Ammonites." Only an abstract of the paper was published §. Nautili and Ammonites were exlibited in illustration of the paper, and, according to the abstract, "Two specimens exhibited show long spatulate depressions more or less parallel to the periphery for about half the length of the body-chamber. It was suggested that these impressions indicated the position of the shell-muscles."

So far, then, as I lave been able to ascertain, no satisfactory examples exhibiting the form and position of the muscular attachment of the Ammonoid animal to its shell have yet been figured and described either to confirm or to contradict the explanation which Waagen gave of Oppel's figures.

The Ammonite animal may have been, and probably was, attached to its shell at the edge of the last septum, as in the living Nautilus, but from my own observations it is

* Abhandl. d. k.-k. geol. Roichsanst. Wien, Bd. vi. Theil i. Ifeft i. (18-3) pl. xvi. f. 3 (Ihylloceras occultum); pl. xix. f. 1 (Piuecocertes transiens) ; pl. xix. ff. 2, 3, 4 \& pl. xx. ff. 8 \& 9 (Pinacoctas lutmile); pl. xx. ff. 2, 3, 5, \& 7 (Pinacoceras insectun) ; pl. xxii. ff. 7, 8 (l'inacoceras myophorum); ibid. Bd. vi. Hälfte ii. (1893) pl. exxxiv. f. 1 (Choristoceras ammonitiforme); ibid. Bid. x. (1882) pl. liii. f. 2 (Megaplygllites sandalinus); pl. liii. f. 3 (Megaphyllites ololus).

† "Ueber einen Ceratiton aus dem Schaumkalk von Rüdersdorf und über grewisse als Haftring gedeutete Eindrücke bei Cephalupoden," Neues Jahrl, lsso, ii. 1. 19, pl. i.

$\mp$ Berichte der naturiorschenden Gesellschaft zu Freiburg, Bd. iv. Heft 3, pl. 31-47 (1889).

$\$$ Abstr. Proc. Geol. Soc. London, Session 1890-91, p. 165 (Quart. Journ. Geol. Soc. vol. xlvii.). 
quite clear that it was furnished with shell-muscles and an annulus like the recent Nautilus, and it is the object of the present communication to record the indications of these structures in various Ammonoids. It is not proposed here to record every Amnonoid in which these impressions have been olsserved-this I hope to be able to do subsequently-but to describe the form and position of these impressions so far as I have been able to observe them in the different forms which the Ammonoids assume, e.g. in Baculites, Hamites, Crioceras, Ancyloceras, Macroscaphites, Scaphites, and Tumilites, the group of the Ammonites (ranging from very evolute to almost entirely involute forms), as well as in Clymenia and the group of the Goniatites.

It may be well at the outset to refer to the indications of the shell-muscles and of the annulus as they exist in the shell of the recent Nautilus, and for this purpose it will probably suffice among the many figures which have been published of the muscular attachment of the recent Nautilus to call attention to the figures accompanying Dr. Waagen's paper already alluded to (p. 71$)^{*}$. I may, however, here remark that in the recent Nautilus the shell-muscles are ear-shaped and situated upon each side of the animal; they are connected both on the dorsal and on the ventril side by a riarrow band-the annulus. The sholl-muscles are not inserted into the shell-substance, but are merely applied to the inner surface of the test with the intervention of a thin layer of conchiolin; and all that is usually preserved in the interior of the sholl to indicate the form and position of the muscular attachment is a fine, generally raised line, corresponding to the anterior boundary of the annulus and of cach sholl-muscle; it is only rarely that there are any indications of the posterior boundary of these structures. On an internal cast this raised line would be represented by an incised line, and since in fossils the remains of the muscular attachment are preserved almost always on internal casts, they therefore exist as incised lines. Such structures have been described and figured in not a few fossil Nautiloids, including the genus Nautilus itself. In the fossil forms any record of the form and position of the muscular attachment would, when present, usually be preserved upon the surface of the natural internal cast of the bodychamber, and hence raised lines on the inner surface of the original test would appear on the internal cast as incised lines, and vice versâ.

In order to observe in the recent Nautilus the exact position of the muscular attachment with relation to the edge of the last septum, an artificial cast of the shell of Nautilus pompilius was made by filling a sagittal section of a recent shell with paraffin wax, and then dissolving away the shelly matrix with hydrochloric acid. The anterior boundary of the muscular attachment alone was indicated by a very finely incised line.

To show the usual position of the muscular attachment in Ammonoids, and for the better understanding of the less perfectly preserved examples, it is proposed first to describe the impressions of the "muscular scars" in the specimen on which they have been most clearly seen, and then the specimen in which the remains of the annulus have been most clearly observed. 'The former is an example of Crioceras from the

* See also the recently-published paper by L. E. Griflin, "Notes on the Anatomy of Nautilus pompilius," Zool. Bull. vol. i. no. 3, pp. 147-161; with bibliography. 
Speeton Clay, and the latter an Oxfordian Ammonite, now referred to the genus Cardioceras. Then it is proposed to describe the form and position of the scars and of the annulus (when seen) in various forms of Ammonoids, ranging from the straight (in the adult) from Baculites, through Hamites, Crioceras, Ancyloceras, Macroscaphites, Scaphites, and Turrilites to the group of the Ammonites; then in Clymenia and the group of the Goniatites.

The very fragmentary character, and consequently imperfect determination, of some of the specimens must be mentioned; but, bearing in mind the position of the shellmuscles in the Ammonoid, viz. on the inner portion of the whorl, it will be at once evident that the traces of the muscular attachment are more likely to be found in fragmentary specimens, principally on natural internal casts of the body-chamber.

\section{Muscular Scars.}

The muscular scars have been best observed in a fragment of Crioceras quadratum *, n. sp., which I obtained from the Speeton Clay of Yorkshire (Pl. 17. figs. 10, 11). It consists merely of the base of the body-chamber, and is about $38 \mathrm{~mm}$. long. The greater part of the test, which was in a very soft, white, friable condition, has been removed by a stiff brush, so as to expose the surface of the internal cast of the body-chamber without scratching it. The section of the whorl is subquadrate, the outer area being somewhat narrower than the inner; at the last septum the height of the whorl is $29 \mathrm{~mm}$., and its greatest thickness $27 \mathrm{~mm}$. On the inner (dorsal) area of the internal cast, and near the posterior extremity of the body-chamber, there are two oval areas, one on either side of the median line, the major and transverse diameters of each being $14 \mathrm{~mm}$. and $11 \mathrm{~mm}$. respectively. The longer diameter of each is placed transversely, but not quite at right angles to the median line, the inner end of this diameter being slightly in advance of the outer extremity. The two impressions are nearly in contact, being only about $0.5 \mathrm{~mm}$. apart at the inner or anterior end of their respective longer diameters; their posterior borders are only slightly in advance of the last septum. Each impression is very slightly roughened, and consequently distinct from the surrounding and somewhat polished surface of the cast. An incised line forms its boundary on the inner, anterior, and outer sides, being deepest on the anterior side, while its posterior boundary is marked by a faint, somewhat irregular and imperfectly-defined line. No trace of the portion of the annulus surrounding the base of the body-chamber, and connecting the muscular impression on the one side with the muscular impression on the other side, can be seen. In the triangular space between the two impressions, and $3 \mathrm{~mm}$. posterior to the point where they are nearest together, there is near each incised line a very small, shallow, double pit, each pair of pits being disposed longitudinally; these doubtless were connected with the muscular attachment of the animal to its shell.

\footnotetext{
* This is really a Bean MS. name. Some of the cxamples of this species in the British Museum Collection bear this name in Bean's handwriting, and I have adopted the name, since, so far as I know, the species has not yet been described.
} 


\section{Annulus.}

The impression of the annulus has been observed in several specimens, but in the British Museum Collection (No. C. 6801) there is an example of Cardioceras excavatum (J. Sowerby)* from the Oxford Clay, but the locality is not recorded, in which the form of the muscular attachment, and particularly that of the annulus, is remarkably well displayed (Pl. 18. fig. 8). The specimen is apparently complete, and shows the aperture of the shell, which is provided with a narrow, ventral (or peripheral) apophysis. Its dimensions are :-Diameter of shell $120 \mathrm{~mm}$; width of umbilicus $24 \mathrm{~mm}$; height of outer whorl $58 \mathrm{~mm}$; ditto above preceding whorl $40 \mathrm{~mm}$; thickness of outer whorl about $43 \mathrm{~mm}$. The body-chamber occupies the last half of the outer whorl, its base being $44 \mathrm{~mm}$. high and $29 \mathrm{~mm}$. wide or thick. The whorl is subsagittate in transverse section; its inner margin slightly overhangs the umbilicus, so that the width of the umbilicus, measured at the umbilical margin, is less than that measured at the suture of the shell. A greater part of the test is preserved, and this is mostly in a soft friable condition. Some of it had been removed from the left + side of the specimen, so as to expose a portion of the internal cast of the base of the body-chamber. By means of a small stiff brush the rest of the test was carefully cleared from both sides of the base of the body-chamber, and the form of the muscular attachment of the animal was displayed very clearly, especially on the left side, the attachment on the right side being precisely similar, but a little less distinct. On the left side the impression of the anterior boundary of the shell-muscle crosses the umbilical margin $5 \mathrm{~mm}$. in advance of the last septum, and passes as a very narrow band of a thin film backward and outward in a flat forwardlyconvex curve as far as the middle of the second lateral lobe, at which point, and $1.5 \mathrm{~mm}$. posterior to it, there is seen to be another similar band which passes from the umbilicus immediately above the saddle on the margin of the umbilicus; these two bands, continuing at about the same distance apart, pass over the lateral saddle into the first lateral lobe and, then diverging slightly, pass over the peripheral or external saddle forward and outward towards the periphery in a flat forwardly-convex curve, but becoming very indistinct before reaching the periphery. These two very narrow filmy bands appear to be the remains of the anterior and posterior boundaries of the annulus respectively.

Remains of the annulus are visible also on the right side, but much less distinctly; they are, however, sufficiently clear to confirm the structures which have been mentioned as existing on the left side.

Having described the usual form of the muscular scars and of the annulus, I now proceed to describe their remains in various forms of Ammonoids, commencing with the genus Baculites and proceeding in the order already indicated (ante, p. 73).

* J. Sowerby, Min. Con. vol. ii. p. 5, pl. cv. (1815).

+ The terms "right" and " left" are used in a strictly morphological sense, the periphery (or siphonal ares) of an Ammonoid being ventral, and the antiperipheral (or antisiphonal) area dorsal. 
Order of Descriptions.

Baculites, Lamarck . . . . . . . . . . . . . . . 77

Hamites, Parkinson . . . . . . . . . . . . . . . 79

Crioceras, Léveillé . . . . . . . . . . . . . . . . . . . . 79

Ancyloceras, d'Orbigny . . . . . . . . . . . . . . . 80

Macroscaphiles, Meek . . . . . . . . . . . . . . . 81

Scaphites, Parkinson . . . . . . . . . . . . . . 81

Turrilites, Lamarck . . . . . . . . . . . . . . . 83

(Heteroceras, d'Orbigny) . . . . . . . . . . . . 84

AMMONI'LES . . . . . . . . . . . . . . . . . . 85

Amatimeid a, Fischer . . . . . . . . . . . . . 85

Oxynoticeras, Hyatt . . . . . . . . . . . . 85

Amaltheus, Montfort . . . . . . . . . . . . . 86

Cardioceras, Neumayr \& Uhlig . . . . . . . . 86

Neumayria, Nikitin . . . . . . . . . . . .89

Tissotia, Douvillé . . . . . . . . . . . . . . 90

Lytoceratid a, Neumayr, emend. Zittel.

Lytocercas, Suess . . . . . . . . . . . . . . . 91

Egoceratids, Neumayr, emend. Zittel.

Arietites, Waagen . . . . . . . . . . . . . 93

Agoceras, Waagen, emend. Zittel . . . . . . . 95

Sonninia, Bayle . . . . . . . . . . . . . . . . 98

Harpoceratide, Neumayr, emend. Zittel.

Hecticoceras, Bonarelli . . . . . . . . . . 98

Ecotranstes, Waagen . . . . . . . . . . . . . 99

Distichoceras, Munier-Chalmas . . . . . . . . 100

Stephanoceratida, Neumayr, emend. Zittel.

Stephanoceras, Waagen . . . . . . . . . . . 101

Perisphinctes, Waagen . . . . . . . . . . . 102

Aspidoceratid e, Zittel.

Peltoceras, Waagen . . . . . . . . . . . . 102

Aspidoceras, Zittel . . . . . . . . . . . . . 103

Cosmoceratide, Zittel.

Parkinsonia, Bayle . . . . . . . . . . . . 103

Prionotropid.x, Zittel.

Schlonbachia, Neumayr . . . . . . . . . . . 104

Clymenia, Münster. . . . . . . . . . . . . . 105

GONIATITES.

Glyphiocer's, Hyatt . . . . . . . . . . . . . . 106 
Baculites, Lamarck.

Baculites ovatus, Say.-An example of this species in the British Museum (No. C. 5415 $\alpha$ ) from the Fox Hill beds (Upper Cretaceous) of Horse-head Creek, South Dakota, U.S.A., displays the impression of the shell-muscles very clearly. The specimen consists of the natural east of nearly the whole of the body-chamber, the cast of the last loculus and of a portion of the penultimate loculus. The test has been almost entirely removed from the posterior part of the body-chamber (Pl. 17. figs. 1, 2, 3). The shell in this species is laterally compressed, and tapers very slowly. The length of the specimen is $290 \mathrm{~mm}$. or about $11 \frac{1}{2}$ inches; its transverse section is oval, the greatest thickness being a little nearer the antisiphonal (dorsal) than the siphonal (ventral) area. Of this length the body-chamber occupies $215 \mathrm{~mm}$., but the aperture is not preserved. The ventro-dorsal and transverse diameters of the base are 38 and $25.5 \mathrm{~mm}$. respectively. The two muscular impressions are at the base of the body-chamber and on the antisiphonal (dorsal) area ; the inner, anterior, and outer portions of their boundaries can be distinctly traced as a faint, shallow, depressed (not sharply-incised) line. On the antisiphonal area the suture-line has a small antisiphonal lobe separating the two portions of a broad saddle, each portion corresponding to the second lateral saddle in an ammonite; each of these halves is followed by a rather broad lobe (the second lateral) which separates it from the saddle occupying nearly the middle of the lateral area, $i . e$. the first lateral saddle. The median line of the antisiphonal area is occupied by a very shallow longitudinal groove. 'The inner boundaries of the two muscular impressions seem to meet in the middle line at about $2.5 \mathrm{~mm}$. in advance of the most anterior part of the saddle, adjoining the antisiphonal Jobe. Starting from this point, the boundary of the impression passes forward and outward until it is $8.5 \mathrm{~mm}$. from the same part of the suture-line; then, turning backward and still maintaining its course outward, it passes along the outer side of the second lateral lobe, close to the inner side of the first lateral saddle. The boundary of the other impression las a precisely similar course. 'The impressions are somewhat oval, their longer diameters making an angle of about $45^{\circ}$ with the median line of the antisiphonal (or dorsal) area. At a point slightly below the level of the most anterior part of the adjoining saddle (the first lateral) the outer boundary of each impression is a little angular. On one (tho right) side of the specimen no trace of the annulus can be seen, but on the other (the left) side a line is seen to pass from the angular portion of the impression outward and upward over, and about $1 \mathrm{~mm}$. distant from, the adjoining saddle; although it can be traced only for a short distance, owing to the roughness of the surface here, it doubtless represents the anterior boundary of a portion of the annulus.

At a distance of $5 \mathrm{~mm}$. in front of the boundary of the impression on the right side, there is another line having precisely the same curvature. It is not nearly so distinct as the one just described, but most probably indicates the anterior boundary of the same shell-muscle. Possibly the posterior line deuotes the position of the shell-muscle during the formation of a septum, and therefore during a period of rest, when the muscle would 
become firmly attached to the shell. The anterior faintly-impressed line may have been the last attachment of the anterior boundary of the shell-musele during the gradual grow th of the animal upward prior to the formation of a new septum. The corresponding line on the left side is obscured by the shelly matter adhering to the cast.

On the median portion of the peripheral area the septum possesses a rather broad (median) saddle, on either side of which is a small lobe-the two halves of the peripheral lobe. This is followed by the peripheral or external saddle. Anterior to the septum and on the central portion of the same area there is a feebly-incised line having the form of half an ellipse (Pl. 17. fig. 3) ; it arises close to the outer portion of the external (or peripheral) saddle, $i . e$ at about $7 \mathrm{~mm}$. from the median line of the siphonal (ventral) area; then curves upward and towards the median line, attaining its greatest height at about $8.5 \mathrm{~mm}$. in front of the median saddle, or about $5.5 \mathrm{~mm}$. from its commencement. The line secms then to pass on to the other side without interruption, but the surface of the cast is not sufficiently well preserved to enable this to be stated with certainty. Its anterior portion is about on the same level as the anterior portion of the boundary of the muscular impression. About $6 \mathrm{~mm}$. in front of this curve there is a similarly-curved feebly-impressed line, which most probably is companable with the faint curve on the opposite (antisiphonal) surface.

Although the annulus is not well shown in this example, there is another specimen $[$ [C. $5415 b]$ in the British Muscum, from the same hovizon and locality (Pl. 17. fig. 4), which displays the muscular impression less distinctly, but clearly shows the anterior boundary of a portion of the annulus. This leaves the muscular impression at the "angle" mentioned in the previous description, and, passing upward over the adjoining saddle at a distance of about $1.5 \mathrm{~mm}$. from the suture-line, crosses the next lolse in a shallow depression, and again rises over the next saddle at about the same distance from it as before. 'This depression, however', is seen only with difficulty and by turning the specimen about in a fairly good light. There can, I think, be no doulbt that the anmulus was in the form of a simply-waved band, being elevated at the saddles and very feebly depressed in each lobe just as in the example of Cardioceras excavatum already described (p. 75). The total length of the specimen is $245 \mathrm{~mm}$., the body-chamber (the aperture of which is not preserved) occupying $165 \mathrm{~mm}$., the diameters of the buse of the body-chamber being 44 and $31.5 \mathrm{~mm}$. respectively. 'The other side of the cast of the body-chamber is obscured by fragments of the test.

Baculites vagina, Forbes.-A portion of the muscular impression has also been seen in an example of this species in the British Muscum Collection [one of the specimens numbered 83621] from the Upper Cretaceous of Pondicherry, India (Pl. 1\%. (ig. 5). It is merely the internal cast of the greater portion of the body-chamber, alout $60 \mathrm{~mm}$. long, anteriorly incomplete, but fairly perfect posteriorly. Its transverse section is oval, the diameters of its anterior end being 24 and $14.5 \mathrm{~mm}$; those of the posterior end being 19 and $12.5 \mathrm{~mm}$. The antisiphonal surface is broad and slightly flattened, the siphonal being narrow, flattened, and with subangular borders. On the broad antisiphonal surface

the feebly convex boundaries of the two muscular scars (indicated by a feebly-incised line 
on the internal cast) meet nearly in the middle line in an obtuse backwardly-directed point which is $3.25 \mathrm{~mm}$. in advance of the saddle on either side of the antisiphonal lobe, these two saddles occupying a large portion of the antisiphonal area. From this point each boundary passes forward and outward for a short distance, then turns backward and sweeps over on to the lateral area in a broad anteriorly-convex curve which gradually disappears before reaching the last septum; if continued to the septum it would meet the large lateral lobe on its antisiphonal side. It would seem therefore that, just as in the Baculites already described, the muscular scar on either side occupied the space between the central line of the antisiphonal area and the antisiphonal side of the large lateral saddle. There is no trace of the annulus in this example.

\section{Hamites, Parkinson.}

Hamites maximus, J. Sowerby *.-In the British Museum Collection (No. C. 6502) there is an example of this species, from the Gault of Folkestone, which displays the form of the inuscular scars exceedingly well (Pl. 17. figs. $(6,7)$. It is only a fragment, i. $e$. one portion (the larger) of the terminal hook, and consists of the internal cast of the last loculus and of a portion of the body-chamber ; its length, measured on the periphery, is about $55 \mathrm{~mm}$. The whorl is subcircular in section, only slightly compressed, its ventro-dorsal diameter (excluding the ribs) at the base of the body-chamber being $16 \mathrm{~mm}$., and its transverse diameter (also excluding the ribs) $15.5 \mathrm{~mm}$. The impressions of the muscular scars are seen on the inner (dorsal) surfice of the east of the base of the body-chamber, one on either side of the median line and disposed somewhat obliquely, just as in the example of Crioceras quadratum alrearly deseribed in this paper (amle, p. 74). Each sear is clliptical in outline, and enclosed by a very faintly-incised line; its longer axis is inclined to the median line of the dorsal surface of the body-chamber at an angle of about $45^{\circ}$; its posterior boundary is only about $1.5 \mathrm{~mm}$. anterior to the antisiphonal saddle of the last septum. Anteriorly the impressions are $1 \mathrm{~mm}$. apart. The longitudinal and transverse diameters of each scar are 12 and $10 \mathrm{~mm}$. respectively. At about the middle of the outer portion of the boundary there is a slight angularity, which doubtless indicates the position of the commencement of the anterior border of the annulus, but no other traces of the annulus have been observed. In another example which is figured (Pl. 17. tigs. 8,9) each muscular scar bears a small roughened patch, and there are indications of a narrow band connecting the scars.

\section{Crioceras, Léveillé.}

Crioceras quadratum $\uparrow$, n. sp.-The muscular impressions in this genus have been best observed in two examples of Crioceras quadratum from the Speeton Clay, Yorkshire. One of these has already been described (see p. 74). The other forms part of the British Museum Collection (No. 89102). It consists of the natural cast of the body-chamber with

* J. Sowerby, Min. Con. vol. i. p. 138, pl. Ixii.(1814).

$\dagger$ See footnote, ante, p. 74 .

SECOND SERIES.-ZOOLOGY, VOL. VII. 
only fragments of the test adhering to it. At the base of the body-chamber the whorl is subquadrate in section, its height being $35 \mathrm{~mm}$., and its greatest width $31 \mathrm{~mm}$. (Pl. 17 . figs. 12, 13). The impressions are not so complete as in the example just described. The anterior margin of each is indicated by a sharply-incised line; both lines almost meet each other in the median line of the inner (dorsal) area at about $10 \mathrm{~mm}$. anterior to the summit of the innermost portion of the saddle on either side of the antisiphonal lobe. Disappearing posteriorly, each passes forward and outward for a length of about $10 \mathrm{~mm}$., when each is about $5 \mathrm{~mm}$. in advance of its origin; then, turning abruptly backward, each gradually disappears at a distance of about $9 \mathrm{~mm}$. from its point of origin and alout $14 \mathrm{~mm}$. from the median line. The posterior extremity of each has a tendency to turn outward, and at a short distance from the extremity the line gives off a very faint branch which turns inward, but can be traced only for a short distance. Without doult the faint line turning inward represents the boundary of the impression of the shell-muscle, and that continuing in an outward direction indicates the position of the anterior border of the adjacent portion of the annulus.

\section{ANCYLOCERAS, d'Orbigny.}

Ancyloceras Matheronianum, d'Orbigny.-In the genus Ancyloceras what is believed to be the impression of the muscular attachment of the animal has been best seen in an example of Ancyloceras Matheronianum in the British Museum Collection (No. C. 5322). It is a natural internal cast from the Neocomian of Cassis (Bouches-duRhône), France (Pl. 17. figs. 14, 15, 16). The coiled part of the septate portion is wanting, but the rest is fairly well preserved, although much waterworn. The body-chainber, measured along the centre of the periphery, is $380 \mathrm{~mm}$. long; the cross section of its base is oval, the dorsal (or inner) portion being somewhat wider than the ventral (or outer); the ventro-dorsal diameter (or height) of the base is $75 \mathrm{~mm}$., the transverse diameter (i.e. the thickness) $54 \mathrm{~mm}$. (excluding the tubercles). What I regard as the impressions of the boundaries of the two muscular scars are seen on the inner or dorsal area. The two scars are not quite symmetrical, that on the right side extending about $15 \mathrm{~mm}$. further forwards than that on the left. These boundary-lines are incised, but they are much coarser than usual. This, however, is probably due to the waterworn condition of the specimen, for the septal sutures, instead of being finely-incised lines as usual, are fairly deep and wide, and indeed have quite the appearance of having been considerably waterworn; and this condition of the septal sutures supports the opinion that the lines about to be described are really the impressions of the boundaries of the muscular scars. That on the right commences at about $3 \mathrm{~mm}$. to the right of the median line and about $20 \mathrm{~mm}$. in front of the large saddle adjoining the antisiphonal lobe; passing forward for about $35 \mathrm{~mm}$. and approaching nearer the median line, it then turns outward, but still continues forward until at about $50 \mathrm{~mm}$. from the last septum, when it turns still more outward and then disappears. That on the left appears to arise about $43 \mathrm{~mm}$. in front of the most anterior portion of the saddle adjoining the antisiphonal lobe, and about 6 mm. from the boundary on the right side; passing forward and outward for nearly 
$20 \mathrm{~mm}$., it is then at alout $58 \mathrm{~mm}$. from the last septum; then with a broad curve it turns backward until it is about $40 \mathrm{~mm}$. from its commencement, when it appears to rapidly die out. Although the impressions of these boundaries may perhaps be more properly termed grooves, their form and position agree so well with what $I$ have observed in somewhat similar forms that I think there can be no doubt as to their nature. I have not been able to observe any trace of the annulus in this example.

\section{Macroscaphites, Meek.}

Macroscaphites gigas, J. de C. Sowerby, sp.-In the genus Macroscaplites what I regard as the anterior boundary of the muscular scar has been observed in an example of Macroscaphites gigas, J. de C. Sowerby, sp., in the British Museum Collection (No. 32608). The specimen is stated to be from the Lower Greensand of the Isle of Wight, but its matrix and state of preservation suggest rather the Kentish Rag (Lower Greensand) in the neighbourhood of Maidstone (Pl. 17. figs. 17, 18, 19). It is a much-compressed internal cast; the greatest diameter of its septate portion is $180 \mathrm{~mm}$.; the length of its body-chamber measured along the centre of the periphery and over the coarse ribs is $350 \mathrm{~mm}$., the height of the base of the body-chamber is $68 \mathrm{~mm}$., the thickness (including the ribs) being reduced by compression to $225 \mathrm{~mm}$. On the right side, at about $15 \mathrm{~mm}$. above the most anterior part of the last septum and $20 \mathrm{~mm}$. from the inner margin of the whorl when viewed laterally, a very fine incised line arises and passes thence as a flat arc forward and towards the inner margin, which it crosses at about $45 \mathrm{~mm}$. in front of the last septum; it then curves backward and comes to within about $10 \mathrm{~mm}$. of the septum, where it is in the middle line of the compressed and somewhat distorted dorsal area. From this point another line, making an acute angle with the line just described, passes forward and outward for rather more than $30 \mathrm{~mm}$., when it curves outward still more and then disappears. These two curved lines we take to be the anterior boundary of the right and left muscular scars respectively; no traces of the annulus have been observed in this example. The material of this natural internal cast is very coarse, and the specimen is so much crushed that the very faint lines bounding the muscular scars can only be followed with difficulty; the boundary is preserved partly as an incised line and partly as a line of colour.

\section{Scaphites, Parkinson.}

Scaphites binodosus, A. Roemer.-The muscular impression can be traced in an example of this species contained in the British Museum Collection (No. C. 5482). It is from the Lower Senonian (Granulaten-Kreide) of Broitzen, near Brunswick. The specimen is a fairly well-preserved, but somewhat distorted internal cast. Its greatest length is $43 \mathrm{~mm}$., and the greatest diameter of the septate portion is $26 \cdot 5 \mathrm{~mm}$. (Pl. 17. figs. 20, 21). At the posterior end of the body-chamber the whorl is $13.5 \mathrm{~mm}$. high and $10.5 \mathrm{~mm}$. thick (excluding the tubercles). The whorl is somewhat crushed obliquely, so that its sloping inner area is much more clearly seen on one (the left) side. On this side a feebly-incised (partly double) line arises almost close to the last septum, and at a distance of $5 \mathrm{~mm}$. 
from the inner edge of the whorl; passing forward in a broad, flattened, forwardlyconvex curve, it gradually approaches and finally crosses the inner edge of the whorl at about $7 \cdot 5 \mathrm{~mm}$. in front of the last septum. Passing on to the dorsal (or concave) portion of the whorl, it turns backward, and in a rather broad forwardly-convex curve nearly reaches the centre of this urea, where it appears to be joined by the corresponding impression on the opposite side. The boundary of the impression on the opposite side is not quite so distinct, and on the sloping inner area of the whorl it appears to be a little nearer the inner edge of the whorl than on the opposite side, but this is doubtless due in great measure to the oblique crushing to which the specimen has been subjected. At the base of the body-chamber it is only $2.75 \mathrm{~mm}$. from the inner edge of the whorl; passing forward it gradually approaches and finally crosses the same at about $7 \cdot 5 \mathrm{~mm}$. in advance of the last septum. Passing thence in a forwardly-convex curve, it joins its fellow at about the centre of the dorsal surface of the whorl.

The lines here described are probably the boundaries of the muscular scars. I have not seen any indications of the annulus in this specimen.

Scaphites aqualis, J. Sowerby.-The muscular attachment of the animal has also been observed in an example of Scaphites aqualis, J. Sowerby, in the British Museum Collection (larger of the two specimens, No. 89113). The specimen is an exceedingly well-preserved and almost perfect natural internal cast from the Lower Chalk of Dorset. The greatest length of the specimen is $29 \mathrm{~mm}$; the greatest diameter of the septate part (which is at the base of the body-chamber) is $15.5 \mathrm{~mm}$., the whorl here being $9 \mathrm{~mm}$. high and $11 \mathrm{~mm}$. wide (excluding the tubercles). The mouth-border is well preserved. The anterior border of the muscular attachment is preserved on the lateral area as a very faint line arising (on the left side) almost close to the last septum and at about $1.5 \mathrm{~mm}$. from the edge of the whorl, and passing forward and towards the edge of the whorl crosses this edge somewhat obliquely at about $6.5 \mathrm{~mm}$. in advance of the last septum. Fortunately a portion of the body-chamber can be removed so that the course of this line can be satisfactorily traced. Continuing still forward it passes into a fairly wide shallow groove $4 \mathrm{~mm}$. in front of the most anterior portion of the septate part of the shell, the groove being disposed across the floor or concave portion of the body-chamber in a flat forwardly-convex curve, with a very slight backward depression at the centre of the area. A similar fine line can be somewhat less distinctly traced on the right side of the specimen, passing into the same groove on the floor of the body-chamber. About $3.75 \mathrm{~mm}$. posterior to the groove just mentioned there is another similar but narrower groove. From my examination of other specimens it is not unlikely that this will prove to be the posterior boundary of the shell-muscles, which seem to have been united on the concave portion of the body-chamber into a fairly wide band. The shell-muscles then appear to have been almost confined to the concave area of the body-chamber, only a narrow portion extending on to the lateral area.

In the British Museum Collection (No. C. 6800) there is also a fragmentary example of the same species (Pl. 17. fig. 22), from the concave portion of the body-chamber of which the matrix has been removed as carefully as possible. There is a similar line on the lateral 
area, passing into a shallow groove on the concave portion of the body-chamber, but the part of the latter between the groove and the anterior impressed line produced by the ornaments of the septate part of the shell is covered with a thin, ycllowish, powdery layer, quite unlike the rest of the concave portion of the body-chamber. This in all probability indicated the place of attachment of the shell-muscles.

I have not observed the remains of the annulus in any example of this species that has come under my notice.

\section{T'URRTLITEs, Lamarck.}

Turrilites luberculatus, Bosc.-An example of this species in the Museum of Practical Geology (No. 6372) from the Lower Chalk of Cliffe Anstey, Wilts, displays the anterior border of the muscular scars exceedingly well (Pl. 18. figs. 1, 2). The specimen is a natural internal cast of about five whorls, the smallest of which is somewhat imperfect, and the rest fairly well preserved. Two of the upper whorls show that the siphuncle (si) is situated at about one-sixth of the height of the whorl below the suture of the shell. Unfortunately the suture-line is not well shown, so that it is not possible to say exactly where the body-chamber commences. The aperture is farly well preserved. The height of the last whorl (from the lowest of the three rows of small tubercles to the suture of the shell) is about $52 \mathrm{~mm}$; the width of the whorl (i.e. the distance across the specimen) being $1085 \mathrm{~mm}$. The anterior border of the muscular attachment is well shown on the last whorl as a well-marked narrow groove. Vicwing the specimen with the aporture away from you and directed downward, the course of this groove may be thus described:Commencing somewhat below the centre of the whorl it passes for a very short distance (about $2 \mathrm{~mm}$.) downward and to the right; then, turning still more to the right, it passes for a distance of about $13 \mathrm{~mm}$. with a bold convex curve to within $12.5 \mathrm{~mm}$. of the lowest row of smaller tubercles; then turning again still more to the right it passes under the uppermost row of small tubercles. Tust beneath the tuberele to the left of the one under which this groove passes there are indications of a septal suture; this is believed to be the last septum, and therefore to indicate the commencement of the bodychamber. Passing still to the right and downward in a broad fecbly-convex curve, and at the same time becoming deeper, the groove crosses the two lower rows of small tubereles at about $30 \mathrm{~mm}$. from the last-mentioned bend; it is continued on to the surface below the tubercles $u n t i l$ at abont $10 \mathrm{~mm}$. below the lowest row it curves round in a broad curve and passes to the left for a short distance; then at about $21 \mathrm{~mm}$. below the lowest row of tubercles it makes an angular bend, passes downward and to the left for a distance of 1.1 mm., when it curves upward and passes into the umbilicus; this upward portion can be traced lor about $24 \mathrm{~mm}$., when it is obscured by matrix. With the exception of the $15 \mathrm{~mm}$. first describel, probibly the whole of this incised line represents the anterior boundary of the two muscular scars.

Turrilites Mantelli, Sharpe-An inperfect example of this species in the Museum of Practical Geology (No. 6373), from the Lower Chalk of the Isle of Wight, also shows a portion of the anterior border of one of the muscular scars (Pl. 18. fig. 3). The specimen 
consists of the natural cast of only two whorls. The aperture is not preserved, but a portion of the last whorl without doubt formed part of the body-chamber. The larger whorl is $30 \mathrm{~mm}$. high ( $i . e$. from the lowest row of tubercles to the suture of the shell), and measures $65 \mathrm{~mm}$. from side to side. The anterior border of the muscular impression occurs as an impressed line very near the anterior end of the specimen. Viewing the specimen with the large whorl downward, this line commences a little below the middle of the whorl, and, crossing the uppermost of the three rows of small tubercles, turns somewhat abruptly to the right, becomes more deeply impressed, and with a bold anteriorly-convex curve crosses the other two rows of small tubercles and passes on to the sloping surface below the tubercles, being intercepted at about 11 mm. below the lowest row of tubercles by the broken anterior end of the specimen.

Although the impression in this specimen is very incomplete, it serves to confirm the structure which has just been described in Turrilites tuberculatus.

\section{Subg. Heteroceras, d'Orbigny.}

Turrilites (Heteroceras) polyplocus, Roemer.-It is exceedingly interesting to have been able to recognize any indications of the muscular attachment in this subgenus of Turrilites, since here the shell is coiled in the opposite direction to that of the genus Turrilites, and hence a corresponding inversion of the muscular attachment was to be expected. The example of Turrilites (Heteroceras) polyplocus, Roemer, in which the attachment has been seen forms part of the British Museum Collection (No. 46454) and is from the Upper Cretaceous rocks of Haldem, Westphalia (Pl. 18. fig. 4). The specimen consists of about one and a half whorls. The aperture is exceedingly well preserved, but the suture-line is not shown, so that the base of the body-chamber cannot be thereby recognized. The form of the right side of the attachment is seen in fig. 4 . Viewing the specimen as represented in the figure, the line indicating the anterior boundary of the muscular attacbment is seen as an impressed line to commence on the lateral area of the whorl just to the right of the tubercle, which is above and somewhat to the left of the aperture; passing downward it turns to the left immediately under the tubercle, and continues to pass downward for rather more than $20 \mathrm{~mm}$; having turned upward very slightly, it continues as a line of colour in a broad sweep, nearly parallel to the outer curve of the whorl, to within about $60 \mathrm{~mm}$. of the border of the aperture, when it again becomes a finely-incised line; then, turning upward and still passing forward for about another $20 \mathrm{~mm}$, it curves somewhat abruptly backward, continuing for about $20 \mathrm{~mm}$. ; this last portion of the line enclosing an oval area, open posteriorly, the diameters of which are 20 and $12 \mathrm{~mm}$. respectively. This area I regard as one of the muscular scars, and the line leading up to it as being partly the boundary of the shell-muscle, and partly the boundary of the annulus. It is much to be regretted that in developing the specimen its surface was somewhat scratched and rubbed, so that it is not possible satisfactorily to follow the course of the impression on the other side of the whorl. 


\title{
AMMONITES *.
}

\author{
A M A L T H I D E, P. Fischer.
}

Oxynoticeras, A. Hyatt.

Oxynoticeras ? sp.-The example (Pl. 18. figs. 5,6) apparently referable to this genus, in which the form of the muscular attachment has been observed, is from the Great Oolite (Stonesfield Slate) of Stonesfield, Oxfordshire, and forms part of the British Museum Collection (No. 36710). It has been labelled "Ammonites discus, J. Sowerby," but it is probably not referable to Sowerby's species $\dagger$, although its state of preservation does not allow an accurate determination. It is a crushed, poorly-preserved, internal cast lying loose on a piece of matrix. The greater part of the specimen is septate; the bodychamber has been broken across obliquely, but fortunately the posterior portion is preserved. When complete the specimen probably was quite $145 \mathrm{~mm}$. in diameter, and its umbilicus about $22 \mathrm{~mm}$. wide. The last half-whorl at least was occupied by the body-chamber, the base of which is $52.5 \mathrm{~mm}$. high and about $10 \mathrm{~mm}$. thick. The anterior border of the muscular scar and of the annulus can be traced across each side of the specimen, but it is more distinct on that side(fig. 5) lying upon the matrix. Here the anterior border arises from the suture of the shell at a distance of $11.5 \mathrm{~mm}$. in advance of the last septum; after passing forward and outward for a short distance it turns backward in a rather broad curve, and passes uninterruptedly across the body-chamber in a fairly straight line, which is almost parallel to the general direction of the last septum, being in advance of the septum $15.5 \mathrm{~mm}$. on the inner portion of the lateral area and $21 \mathrm{~mm}$. near the periphery, where it seems to turn backward a little, but this appearance may be due to the much-compressed state of the fossil; it has no depressions corresponding to the lobes of the suture-line. The portion of the border to a distance of about $13 \mathrm{~mm}$. from the inner edge of the whorl is indicated by a well-marked depressed line, and the rest of the border is indicated by the anterior boundary of a band of colour about $4.5 \mathrm{~mm}$. wide, the posterior boundary of which is not sharply defined. The inner portion, bounded anteriorly by the depressed line, doubtless represents the muscular scar, and the broad band of colour the annulus; the scar exhibits distinct lines of growth.

On the opposite side the muscular scar and annulus are less clearly defined. The muscular impression appears to be somewhat nearer the last septum, for its anterior boundary arises as a faintly-incised line at a point only $8.5 \mathrm{~mm}$. in advance of the last septum, and passes outward and backward as far as the septum, which it meets at a distance of $8.5 \mathrm{~mm}$. from the inner edge of the whorl. Before reaching the septum, i. $e$. at a distance of $3.5 \mathrm{~mm}$. from the septum, this boundary gives off a branch (indicated by a line of colour) which can be traced as a slightly-waved line across the body-chamber to the periphery, where it meets the anterior boundary on the opposite side. The portion of the annulus adjoining the muscular impression on this side is only about

* The nomenclature and grouping of the Ammonites here adopted are those given by Prof. Dr. K. A. v. Zittel in his 'Grundzüge der Paläontologie,' 1895.

† J. Sowerby, Min. Con. vol. i. p. 37, pl. xii. (1813). 
$1.5 \mathrm{~mm}$. wide for a length of about $8.5 \mathrm{~mm}$; it then expands somewhat rapidly to a width of $4.5 \mathrm{~mm}$., a width which it maintains across the rest of the body-chamber, joining the band on the opposite side, the portion near the periphery being, however, somewhat less distinct than the rest.

The discrepancy in the position of the two impressions is doubtless due in a great measure, if not entirely, to the crushing which the specimen has undergono during fossilization.

\section{Amaltheus, Montfort.}

Amaltheus spinatus, Bruguière, sp.-The muscular impression has been observed in an example of this species in the British Museum Collection (No. C. 4919), the locality of which is not recorded. 'The specimen consists of the well-preserved septate portion of the shell, together with a nat ural cast of one side of the dorsal (or inner) part of the posterior portion of the body-chamber (Pl. 18. fig. 7). The dimensions of the specimen at the base of the body-chamber are:-diameter of the shell $57 \mathrm{~mm}$; width of umbilicus $24 \mathrm{~mm}$.; height of onter whorl $19 \mathrm{~mm}$; ditto above preceding whorl about $17 \mathrm{~mm}$.; thickness of outer whorl (excluding ribs) $19 \mathrm{~mm}$; ditto (including ribs) $22 \mathrm{~mm}$. A portion only of the anterior boundary of the muscular impression is preserved. This, which appears as an impresserl line, arises almost close to the suture (of the shell) $9 \mathrm{~mm}$. in front of the anterior part of the small saddle belonging to the last suture-line that is situated on the edge of the umbilicus; it curves outward and backward for a distance of about $5 \mathrm{~mm}$. where it is about $4 \mathrm{~mm}$. from the suture (of the shell); then, passing backward nearly parallel to the inner edge of the whorl, it appears to divide just before meeting this small saddle, one part passing on the inner (dorsal) side of the small saddle situated on the edge of the umbilicus and then disappearing, the other passing on the outer side of the same saddle and then also disappearing. Posterior to this distinctly-impressed line there are several very faint lines concentric with it.

\section{Cardioceras, Neumayr \& Uhlig.}

Cardiocevas excavatum, J. Sowerby, sp.-In the description of the annulus, which has already been given, I have described the muscular attachment in an example of this species (see ante, p. 75 ).

Another example of this species is also figured which shows the course of the anterior boundary of the musculai scar on the dorsal or impressed portion of the whorl (Pl. 19. figs. 1, 2).

Cardioceras aff. excavato, J. Sowerby, sp.-'The muscular impression is also shown in an example of Cardioceras in the British Museum Collection (No. 50098), but its locality is not recorded ( $\mathrm{I}^{\prime} \mathrm{l}$. 18. figs. 9, 10). It is, however, allied to Card. excavatum, but is more compressed and more widely umbilicated than that species. The dimensions of the specimen are:--diameter of shell $51 \mathrm{~mm}$.; wilth of umbilicus $18.5 \mathrm{~mm}$.; height of outer whorl $20 \mathrm{~mm}$; thickness of outer whorl $12 \mathrm{~mm}$. The test has been removed 
from the greater part of the body-chamber, and the latter can fortunately be removed from the rest of the specimen. The whorl is carinate, subquadrangular in transverse section, its sides much flattened and nearly parallel to each other; at the base of the hody-chamber it is $13.5 \mathrm{~mm}$. high and $10 \mathrm{~mm}$. thick. On the left side of the specimen (Pl. 18. fig. 9), near the base of the body-chamber a feebly-impressed (on the internal cast) line arises from the suture of the shell (i.e. the inner edge of the whorl) $15 \mathrm{~mm}$. in front of the last septum; it extends outward and backward almost as far as the septum, nearly reaching the same at the inner side of the second (or inferior) lateral lobe; it then turns outward, as if to pass over the adjoining saddle, and soon disappears. When the body-chamber is detached (Pl. 18. fig. 10) this incised line is seen to be continued on to the impressed zone, being also indicated by a difference of colour, the portion posterior to the boundary being much lighter than the rest of this surface. From the edge of the whorl this boundary passes a little backward in an $f$-shaped curve noarly to the central line of the impressed area, when, turning abruptly backward, it passes nearly parallel to the median line of this area as far as the small saddle adjoining the antisiphonal lobe. The corresponding line on the other side of the impressed area has the same form, so far as it can be traced, but the edge of the whorl on this side is somewhat imperfect. A line of colour appears to indicate that the median space between the two boundaries was bridged over anteriorly. 'The form of the muscular attachment just described on the impressed area of the outer whorl is confirmed by its appearance on the inner surlace of the dorsal portion of the test of the body-chamber, which remains attached to the preceding whorl.

'The muscular scar on the right side of the body-chamber is not preserved, the inner portion of the base of the hody-chamber having been broken off.

On the middle of the left lateral area there is a linguiform space, $8 \mathrm{~mm}$. long and 1 $\mathrm{mm}$. broad, enclosed by a very faint line, open behind and convex anteriorly (Pl. 18. fig. ()). Its lateral boundaries are nearly parallel to the inner and outer margins of the whorl respectively, the inner being $45 \mathrm{~mm}$. distant from the inner maroin, and the outer at the same distance from the periphery of the whorl. The inner boundary passes just into the inferior lateral lobe along its outer side, and the outer boundary just passes into the superior lateral lobe along its inner side. There is a similar linguiform area on the middle of the right side of the body-chamber, $9.5 \mathrm{~mm}$. long and $6 \mathrm{~mm}$. wide, open behind, and with a convex anterior boundary. Its inner boundary passes just into the inferior lateral lobe at its outer side, whilst the outer boundary passes just into the superior lateral lobe along its outer boundary, and not its inner, as on the opposite side of the body-chamber. Hence the linguiform area on this side is som'what broader than that on the left side, the inner boundary being at about the same distance from the inner edge of the whorl, while the outer is nearer the periphery than on the opposite side.

Only in this one specimen have these linguiform areas been observed; but, as they are so distinctly displayed on both sides of the fossil, it is just possible that they are connected with the attachment of the animal to its shell. This example seems to support the figure given by Trautschold.

SI:COAD swirs.-zoonogy, vot. vil. 
Cardioceras Sutherlandice, J. de C. Sowerby, sp.-The position of the anterior boundary of the shell-muscle is exceedingly well shown in a large example of this species from the Oxfordian of Scarborough, Yorkshire. It forms part of the British Museum Collection (No. 82369). It is a large internal natural cast, about $370 \mathrm{~mm}$. (or nearly ${ } 4 \frac{3}{4}$ inches) in diameter, the umbilicus being $85 \mathrm{~mm}$. in diameter, and having almost perpendicular walls. Nearly one-half of the outer whorl is occupied by the bodychamber, the base of which is obtuscly cordate in section, $132 \mathrm{~mm}$. (or nearly $5 \frac{1}{4}$ inches) high and $210 \mathrm{~mm}$. (or rather more than $8 \frac{1}{4}$ inches) wide, the inner area being $45 \mathrm{~mm}$. wide and nearly perpendicular to the plane of symmetry of the shell. The anterior boundary of the muscular impression, represented by a well-marked groove, crosses the umbilical margin $60 \mathrm{~mm}$. (or about $2 \frac{3}{8}$ inches) in front of the last septum, and passing outward and backward becomes much less distinct at about $52 \mathrm{~mm}$. from the last septum, and at about the same distance from the umbilical margin. It appears, however, to be continued across the whorl by a faint, somewhat irregular groove, which, originating some $6 \mathrm{~mm}$. posterior to the groove just described, crosses the whorl in a flat forwardly-concave curve which is only $15 \mathrm{~mm}$. from the anterior portion of the lateral saddle, and nearly touches the anterior part of the external saddle; this we regard as the anterior boundary of the annulus. Passing inward from the umbilical margin, the boundary of the shell-muscle is indicated by a distinct groove which curves somewhat backward, but can be traced only about halfway across the inner area of the whorl.

Cardioceras funiferum, J. Phillips, sp.-A similar boundary of the shell-muscle has been observed in several examples of this species which are contained in the British Museum Collection. It is well shown in an example (No. 50447) from the Oxford Clay of 'Trowbridge, Wiltshire. 'This is $167 \mathrm{~mm}$. in diameter and $68 \mathrm{~mm}$. thick, the umbilicus being almost closed and its margin rounded. About one-half of the outer whorl is occupied by the body-chamber, the base of which is acutely cordate in section, $64 \mathrm{~mm}$. wide and $72 \mathrm{~mm}$. high. On the left side of the specimen the anterior border of the shell-muscle is indicated by a groove which crosses the umbilical margin at $9 \mathrm{~mm}$. anterior to the last septum; passing backward and outward as a fairly wide groove for about $10 \mathrm{~mm}$., it then becomes shallower and wider. The posterior boundary of the muscular scar is represented by a slightly raised ridge, which, passing from the umbilical margin just above the last septum outward and forward, meets the lower boundary of the anterior groove at a point $12 \mathrm{~mm}$. from the umbilical margin. The anterior groove appears to be continued across the whorl ( $i . c$. to within $5 \mathrm{~mm}$. of the periphery) as an exceedingly faint groove, which indicates the position of the anterior border of the annulus; this is $8 \mathrm{~mm}$. anterior to the lateral saddle, $.20 \mathrm{~mm}$. anterior to the external saddle, and is depressed at each lobe. On the outer half of the lateral area of the whorl this boundary is partly indicated by remains of the test.

On the right side of the specimen there are similar indications of the anterior boundary of the muscular scar, but no traces of the annulus. 
Cardiocer'as sp.-Indications of the muscular attachment are well displayed in a small Ammonite from the Upper Jurassic of Kintradwell, Sutherland, which forms part of the British Museum Collection (No. C. 4389). Although the specimen is fairly well preserved, I have not been able satisfactorily to determine the species, but it seems to be referable to the genus Cardioceras (Pl. 19. figs. 3, 4). Its dimensions are as follows:diameter of shell $23.5 \mathrm{~mm}$; greatest thickness $8.5 \mathrm{~mm}$; wirlth of umbilicus $7 \mathrm{~mm}$.; height of outer whorl $8 \mathrm{~mm}$. The last two-fifths of the outer whorl are occupied by the body-chamber; the test having been removed from the left side and from the periphery of this portion of the whorl, the internal cast is well displayed. Unfortunately only a small portion of the last suture-line can be made out, the rest being obscured by the test. The portion of the last septum adjacent to the suture of the shell is obscured. but on the internal cast of the body-chamber, at a short distance anterior to the last septum, a very fine incised line arises from the suture of the shell, passes inward in an almost radial direction for about $25 \mathrm{~mm}$., then turns backward for about $0.5 \mathrm{~mm}$, and again resumes its radial direction across the whorl, beiug feebly depressed as it passes over each lobe, and slightly raised in passing over each saddle; it is about $0.5 \mathrm{~mm}$. above the latcral saddle and almost touches the most anterior portion of the external saddle. As it approaches the periphery it turns forward to join a somewhat poculiar-shaped roughened scar represented in fig. 4, the posterior inflated portion of which is rather rougher than the rest. Unfortunately the opposite side is obscure? by matrix. The periphery of the posterior portion of the body-chamber scems to be somewhat deformed, and to possess a feeble keel with a shallow sulcus on either side; this deformation may account for the median division of this sear, which probalbly was originally horseshoe-shaped, as olserved in several other Ammonoids.

The portion of the incised line near the suture of the shell doubtless represents the position of the anterior border of one of the shell-nuscles, the rest of the line indicating the position of the anterior boundary of the annulus, there having been, in addition, a firm attachment at the centre of the periphery.

\section{Neumayria, Nikitin.}

Neumayria catemulata, Fischer, sp.-In the 13ritish Museum Collection there is an example of this species exhibiting the form of the muscular attachment. It is a badlycrushed internal cast from the Portlandian of Choroschowo, near Moscow, Russia. The specimen is $119 \mathrm{~mm}$. in diameter, the width of the umbilicus (from suture to suture) being $18 \mathrm{~mm}$., the height of the outer whorl $58 \mathrm{~mm}$., and its thickness $26 \mathrm{~mm}$. The inner aren of the whorl slopes towards the umbilicus and at the base of the body-chamber is $6 \mathrm{~mm}$. wide, the height of the whorl here being $43.5 \mathrm{~mm}$., and its greatest thickness, which is at a short distance from the umbilical margin, $15.5 \mathrm{~mm}$. The last two-thirds of the outer whorl are occupied by the body-chamber. The whorl is sagittate in cross section. 'The muscular impression is well shown on one side, but the crushed condition of the specimen has obliterated it on the other side. Arising from the suture at ahout $7 \mathrm{~mm}$. from the base of the body-chamber, the boundary of the impression, in the form of a faintly-indented 
line, passes outward and backward in a curve, which nearly meets the last septum at about $11.5 \mathrm{~mm}$. from the suture, and thus encloses a subtriangular area on the inner side of the base of the body-chamber. Just before this outer line reaches the last septum it gives off a very faint branch which passes outward towards the periphery, but can be traced for a very short distance only. This is, without doubt, an indication of the anterior boundary of a portion of the annulus. Within and parallel to the outer boundary of the impression there are one or two very faintly indented lines.

\section{'T'isso'tra, Douvillé.}

Tissotic Ewaldi, v. Buch, sp.-The muscular impression is shown in an example of this species in the British Museum Collection (No. C. 4.810 a) from the Chalk (Senonian) of Mezab-el-Mesai, $\Lambda$ lgeria (Pl.18. tig. 11). The specimen is a natural cast, $88.5 \mathrm{~mm}$. in diameter; rather more than one-fourth of the outer whorl is occupied by a portion of the hody-chamber, but this latter is somewhat imperfect on one side, so that the dimensions of the specimen can best be taken at the base of the body-chamber. Here its dimensions are as follows :- diameter of shell $84.5 \mathrm{~mm}$.; width of umbilicus $8.5 \mathrm{~mm}$.; height of outer whorl $42 \mathrm{~mm}$; greatest thickness of same (at a short distance from the umbilicus) $47 \mathrm{~mm}$. The whorl is obtusely cordate in transverse section, rather wider than high, and indented to rather more than one-half of its height by the preceding whorl. The anterior border of the muscular impression is represented by a feebly-incised line. It cannot be traced quite as far as the suture of the shell, but on the narrow inner area of the whorl it is $4 \mathrm{~mm}$. from the last septum; passing thence forward and outward on to the lateral area, it attains its greatest distance from the last septum (viz. $8.5 \mathrm{~mm}$.) at $4 \mathrm{~mm}$. from the edge of the whorl. Then, curving backward, it passes on the umbilical side of, and at a distance of $15 \mathrm{~mm}$. from, the first (counting from the umbilicus) large lateral saddle, and, turning forward, sweeps round in an anteriorly-concave curve immediately about the small saddles occupying the margin of the umbilicus and soon disappears. 'The muscular scar thus bounded appears to have been an oval about $10 \mathrm{~mm}$. by $7 \mathrm{~mm}$, its longer axis being placed nearly in a radial direction but slightly inclined backward. From the anterior portion of the boundary of this impression a feebly-depressed line passes backward and outward in a broad forwardly-convex curve to within about $2.5 \mathrm{~mm}$. of the outer portion of the first (counting from the umbilicus) large lateral saddle, then in a forwardly-concave curve crosses the adjacent lobe, and disappears just above the next lateral saddle. This line may indicate a portion of the anterior boundary of the annulus.

'I'he opposite side of the body-chamber has been so much eroded that the muscular impression is not preserved. 
L Y T O C E R A T I A, Neumayr, emend. Zittel.

\section{LYT'OCERAS, Suess.}

Lytoceras comucopice, Young \& Bird, sp.-The impression of one of the shell-muscles has been observed in an example of this species in the British Museum (No. 37851) from the Upper Iias of Whitby, Yorkshire (Pl. 19. figs. 15, 16, 17). The dimensions of the specimen are:-diameter $22 \mathrm{~mm}$; width of umbilicus $8 \mathrm{~mm}$.; height of outer whorl $8 \mathrm{~mm}$; greatest thickness of the outer whorl $8.5 \mathrm{~mm}$. Rather more than one-hall of the last whorl is occupied by the body-chamber, the base of which is nearly circular, its dorso-ventral and transverse diameters being each $6 \mathrm{~mm}$. The amount of indentation by the preceding whorl is very small. At the base of the body-chamber, and on the inner area of the whorl, there is an oval impression (fig. 16), truncated on the inner side by the edge of the "impressed zone." 'I'he diameters of the portion that can be seen are $1.75 \mathrm{~mm}$. and $2.0 \mathrm{~mm}$. respectively, the longer diameter being placed transversely on the whorl. The anterior and the posterior boundaries are both visible, the latter being almost close to the first auxiliary saddle; but no trace of the annulus can be seen.

On the peripheral area there is an elongated linguiform impression (fig. 17), which is rounded and submucronate anteriorly, but is open posteriorly, each limb being situated in each half of the siphonal (peripheral) lobe. Its anterior portion is a little in advance of the most anterior part of the siphonal sardle; its posterior portion is slightly contracted. Its length is $3.25 \mathrm{~mm}$. and its width (between the limbs) $75 \mathrm{~mm}$.

In the British Museum Collection there is also a portion of the natural internal cast of the body-chamber of another example of this species (Pl. 19. figs. 13, 14), from the Upper Lias of Whitby, which exhibits the impression of the boundary of the right muscular scar surrounded anteriorly and laterally by a dark-coloured, longitudinally-elongated, oval area, a portion of which is slightly rougher than the rest. Its form is shown in fig. 13. Only the right side of the base of the body-chamber is preserved, the height of the whorl here being $35 \mathrm{~mm}$. At about $45 \mathrm{~mm}$. anterior to the last septum, the incised line indicating the position of the boundary of the muscular scar passes from the suture of the shell-i.e. the edge of the impressed zone-in a radial direction for about $7 \mathrm{~mm}$.; then, turning abruptly backward nearly at right angles to its former course, it is continued as far as the last septum. At the suture of the shell the boundary of the oval dark-coloured area is $3.5 \mathrm{~mm}$. anterior to the incised line just mentioned; after proceeding forward in an anteriorly-concave curve for about $2 \mathrm{~mm}$., it passes in an anteriorly-convex curve forward and outward for about $7 \mathrm{~mm}$; then, after curving gently backward for about $5 \mathrm{~mm}$., it can be traced nearly as far as the last septum, having a direction nearly parallel to the edge of the impressed zone.

Lytoceras fimbriatum, J. Sowerby, sp.-The muscular impression is also shown in a fragmentary example of this species in the British Museum (No. 20837) from the Middle Iias of Kilsby Tunnel, Northamptonshire. The specimen consists of nearly half a whorl, and is a natural cast of part of the body-chamber of a shell having approximately the 
following dimensions :- diameter $120 \mathrm{~mm}$.; width of umbilicus $49 \mathrm{~mm}$; height of outer whorl $44 \mathrm{~mm}$.; greatest thickness of ditto $41 \mathrm{~mm}$. The posterior portion of the body-chamber is preserved; one side is much crushed, but the rest is fairly complete. A portion of the test still adheres to the east. The specimen, measured along the median line of the periphery, is $165 \mathrm{~mm}$. long; its transverse section is ovate, the greatest thickness being at about two-fifths of the height of the whorl from the inner edge; at its postcrior end the height of the whorl and its thickness (allowing for the crushing) are $30 \mathrm{~mm}$. and $27 \mathrm{~mm}$. respectively. The impression of one shell-muscle is well shown, lut only the inner portion of the other (Pl. 19. figs. 11, 12). The whorl is very slightly impressed by the preceding whorl. In shape the impression is truncated-oval, its longer liameter being transverse and the truncated end towards the median line of the dorsal surface. Arising a little in advance of the saddle on the side of the antisiphonal lobe, the boundary of the impression passes forward for about $5 \mathrm{~mm}$. nearly parallel to the median line of the dorsal or antisiphonal surface, and at $1.5 \mathrm{~mm}$. from its fellow on the opposite side; then, curving outward, it extends for about $10 \mathrm{~mm}$. in a direction almost at right angles to its previous course; bending rather abruptly backward, it passes for a short distance nearly parallel to the boundary of the impressed zone; tehn, curving inward and backward, it speedily disappears. 'The greatest width (transverse) of the impression is $12 \mathrm{~mm}$. There is no trace of the annulus. The boundary of the impression is indicated by a depressed line, which is rather deeply incised on the inner and outer portions, but somewhat less so on the anterior portion. The portion of the surface of the cast bounded by the impression is a little rougher than the rest. Owing to the crushed condition of the whorl, only the inner portion of the other impression is preserved. 'The impression is so situated that in a lateral aspect of the whorl only a very small portion of it can be seen (tig. 12).

Lytoceras quadrisulcatum, d'Orbigny, sp.-One example of this species, collected by 1). J. W. Gregory in East Africa, exhilbits a portion of the muscular impressions. It is a crushed fragment of a natural cast of the postcrior part of the body-chamber. The inner portion of the whorl is badly crushed, but exhibits on either side a part of the muscular scar. At the base of the body-chamber the whorl is $30.5 \mathrm{~mm}$. high and $30 \mathrm{~mm}$. thick, the greatest thickness being a little within the central portion of the lateral area ; the transverse section is therefore nearly circular. 'The muscular scars are somewhat darker than the surrounding surface of the cast, and present a slightly roughened appearance. That on the left is the better shown, but its inner portion is obscured so that the whole of its anterior border is not visible. Its boundary is usually a feeblyindented line, but sometimes a slightly-raised line. The anterior boundary of this jimpression appear's to commence at about $7.5 \mathrm{~mm}$. in advance of the most anterior part of the last septum, and about $8 \mathrm{~mm}$. from the central line of the impressed zone; it passes thence slightly forward and outward for a distance of about $2 \mathrm{~mm}$; then, curving backward at about $10.5 \mathrm{~mm}$. from the median line, it passes for a short distance nearly parallel to the median line; then, at about $4.5 \mathrm{~mm}$. in advance of the last septum, 
curving rather abruptly inward but still passing backward, it disappears at about $5.5 \mathrm{~mm}$. from the median line, exhibiting, however, a tendency to again turn forward. The portion of the scar which is visible has a pyriform shape; its axis is at an angle of about $45^{\circ}$ with the median line of the dorsal area of the whorl, the "stalk" being directed outward and backward; its length is about $8.5 \mathrm{~mm}$., and its greatest width about $5 \mathrm{~mm}$.

The other scar is truncated by a fracture crossing it obliquely, so that only the posterior portion of the impression is seen. It is somewhat darker than the surrounding surface, and bounded anteriorly and laterally by a very slightly-raised line. Commencing from the fracture at about $9 \mathrm{~mm}$. in advance of the most anterior part of the last septum, and at the same distance from the median line of the dorsal area, the anterior boundary passes backward and very slightly outward; then, curving round, comes to within 2 mm. of the suture-line; then, curving inward and forward, it is again intercepted by the fracture at about $4 \mathrm{~mm}$. from the median line. The anterior and outer boundaries of the impression are sharply marked by a feebly-incised line, but the posterior boundary is not quite so sharply defined.

There is a very shallow and rather broad depression on the peripheral area about $5 \mathrm{~mm}$. in front of the summit of the siphonal (peripheral) saddle; on either side of the median line of the periphery, and at a distance of $3 \mathrm{~mm}$. apart, a very faint line curves forward and towards the median line of the periphery, nearly meeting its fellow at about $3 \mathrm{~mm}$. anterior to the depression just mentioned. 'This possibly represents the anterior border of the peripheral portion of the annulus.

E G o C E R A T I d E, Neumayr, emend. Zittel.

Arivertes, Waagen, emend. Zittel.

Arietites obtusus, J. Sowerby, sp.*-The muscular impression is well shown in an example of this species from the Lower Lias of Lyme Regis, that was kindly lent to me by Mr. G. F. Harris, F.G.S. The specimen is a fairly-complete internal cast, almost entirely denuded of the test. Its dimensions are:--diameter of shell $101 \mathrm{~mm}$; width of umbilicus $43 \mathrm{~mm}$; height of outer whorl $32 \mathrm{~mm}$; ditto above preceding whorl $29 \mathrm{~mm}$; greatest thickness (excluding ribs) $30 \mathrm{~mm}$; ditto (including rilss) $33 \mathrm{~mm}$. The dimensions of the base of the body-chamber are:- height of whorl $26 \mathrm{~mm}$; thickness (excluding ribs) $22 \mathrm{~mm}$; ditto (including ribs) $25 \mathrm{~mm}$. The body-chamber is complete and occupies the last half-whorl. The muscular impression is situated at the base of the body-chamber and occupies the inner area of the whorl (Pl. 19. figs. 8, 9, 10). Its anterior boundary, represented by a fine incised line, is convex, its anterior portion being $16 \mathrm{~mm}$. in front of the anterior portion of the second lateral saddle of the last septum. Passing backward its outer boundary is nearly parallel to, and at a distance of $6 \mathrm{~mm}$. from, the suture (of the shell). It can be traced backward for a distance of

* Min. Con. vol. ii. p. 151, pl. clxriii. (1817)= Asteroceras obtusum (J. Sowerby) : fide Hyatt, 'Genesis Arietidx,' 1889, p. 201. 
$11 \mathrm{~mm}$, beyond which point the surface of the cast is fractured. About $2 \mathrm{~mm}$. behind this line, and nearly concentric with its anterior portion, there is another very faint line, evidently marking a former attachment of the shell-muscle. On the inner area of the whorl there are three or four fine, faint, longitudinal grooves, extending over three-fourths of the length of the body-chamber; one of these, $2 \mathrm{~mm}$. from the suture (of the shell), extends the whole length of the body-chamber.

On the periphery, on either side of the median line, there is a feebly-impressed sigmoidal line (fig. 10), the anterior portion of which is about $11 \mathrm{~mm}$. in advance of the anterior portion of the external (peripheral or siphonal) saddle. Each line arises about $2 \mathrm{~mm}$. from the median line of the periphery; it passes away from this line, and back ward to about $8 \mathrm{~mm}$. from the most anterior portion of the external (peripheral or siphonal) saddle, and then disappears. 'These lines may indicate the position of the attachment of the animal to this part of its shell, but no comnection can be seen between these lines and the impressions on the inner area. $\Lambda$ line drawn from the centre of the shell to the most anterior part of these lines on the periphery crosses the inner edge of the outer whorl at a point $7.5 \mathrm{~mm}$. posterior to the anterior boundary of the impression which is seen on the inner area.

Posterior to these lines on the peripheral area there is a horseshoe-shaped marking with nearly parallel sides, each of which passes posteriorly into each half of the siphonal lobe. It is rounded anteriorly, and crossed in its length by several lines parallel to the anterior border. Its length (above the small median saddle) is $14 \mathrm{~mm}$., and its width $5 \mathrm{~mm}$. This may, or may not, be connected with the muscular attachment of the animal, but similar impressions have been observed in other forms. (See Aigoceras capricommom, p. 95.)

Arietites ravicostalus, Zieten, sp.*-In the British Museum Collection there is an example of this species (No. C. 4882) showing the muscular impressions (Pl. 20. figs. 10, 11). The locality of the specimen is not recorded, but, judging from the matrix, it came probably from the Lower Lias of Somersetshire. The specimen is a well-preserved natural cast with the following dimensions :-diameter $51 \mathrm{~mm}$; width of umbilicus $33 \mathrm{~mm}$.; height of outer whorl $10 \mathrm{~mm}$.; greatest thickness of outer whorl (excluding ribs) $14 \mathrm{~mm}$; ditto (including ribs) $16 \mathrm{~mm}$. The body-chamber occupies the whole of the last whorl, and its posterior part $(a b)$ can be removed from the rest of the fossil; its transverse section is transversely oval, its thickness (excluding the height of the ribs) heing $10 \mathrm{~mm}$, and its height $7 \mathrm{~mm}$; it was only slightly indented by the broad periphery of the preceding whorl. The greater part of the muscular impressions is on the concave dorsal area, i.e. on the impressed zone. On either side of the median line of this area (fig. 11) there is a subtriangular impression, having its broadly-rounded apex directed forward. These impressions are about $1 \mathrm{~mm}$. apart, that on the right side of the shell being the more nearly complete. Each is bounded by a faint double line. Commencing

* F. Zieten, Verstein. Würt. p. 18, pl. xiii. $\$$. $4=$ Caloceras rapicostatum (Zicten), fide Hyatt, Gen. Arietida, p. 144 . 
at the most anterior part of the antisiphonal (or antiperiphera) saddle and at a point $0.5 \mathrm{~mm}$. from the median line, the boundary of the more nearly complete impression passes forward and outward until it is $3 \mathrm{~mm}$. in advance of the last septum and about $25 \mathrm{~mm}$. distant from the median line; then, turning backward and passing still outward, it approaches the last septum, and nearly (but not quite) meets the inner portion of the lateral saddle, where it disappears, its place of disappearance being $4.5 \mathrm{~mm}$. from the median line of the dorsal area or of the impressed zone. The outer boundary of the muscular impression is on the edge of the umbilicus, and therefore in a lateral view of the Ammonite only the outer backwarlly-directed portion of the impression can be seen. 'There is a corresponding and similar impression on the other side of the specimen, but it is not so complete, owing to a fracture of the fossil. There are no traces of the annulus.

Egoceras, Wagen, emend. Zittel.

Fgoceras capricomum, Schlotheim, sp.--A portion of the impression of the muscular attachment of the animal has been observed in an example of this species from the Lias of Cheltenham, that forms part of the British Museum Collection (No. 67929). The specimen is a well-preserved natural cast, bearing portions of the test in a soft, white, friable condition (Pl. 20. fig. 2). By removing this with a stiff brush from near the base of the hody-chamber, the muscular impression is well shown on either side. The dimensions of the specimen are as follows:-Diameter of shell (inchuding ribs) $47 \mathrm{~mm}$.; ditto (excluding ribs) $1.1 \mathrm{~mm}$; width of umbilieus $20 \mathrm{~mm}$; height of outer whorl (including ribs) $15 \mathrm{~mm}$; d ditto (excluding ribs) $14.5 \mathrm{~mm}$; thickness of whorl (including ribs) $17 \mathrm{~mm}$.; ditto (excluding rilss) $14.5 \mathrm{~mm}$. At the hase of the body-chamber the height and thickness of the whorl are respectively 11 and $1.3 \mathrm{~mm}$. including the ribs, or 10 and $10.5 \mathrm{~mm}$. excluding the ribs. The outline of the muscular impression is seen on either side at the base of the body-chamber and quite close to the suture of the shell. It is convex anteriorly, its anterior boundary being $6 \mathrm{~mm}$. in front of the most anterior portion of the second lateral saddle; its outer boundary is nearly parallel to, and at a distance of $2 \mathrm{~mm}$. from, the edge of the impressed zone, and passes posteriorly on to the outermost branch of the second lateral saddle. Its anterior boundary exhibits a tendency to curve forward at the suture of the shell. In the middle of the peripheral area there is a tongue-shaped sear, which is rather more thim twice as long as wirle, has nearly parallel sides, and is rounded anteriorly; each side of it just touches the boundary of the siphonal lobe. The scar seems to have been covered with a thin film of shelly matter, for part of this has been broken away from the anterior portion so as to expose a black layer beneath. This scar would be situated in the immediate neighbourhood of the siphuncle, and may or may not have had anything to do with the muscular. attaclmment of the animal. Its length above the extremity of the small median saddl. is about $6 \mathrm{~mm}$., and its width is $1.5 \mathrm{~mm}$. $\Lambda$ precisely similar scar las been observed in Arietites obtusus*.

$$
\text { * See ante, 1. } 63 .
$$


'The outline of the muscular impression is also well shown in another example of this species from the Lower Lias, near Whitby, in the collection of F. L. Bradley, Esq., F.G.S., of Alderley Edge, Cheshire, to whom I am greatly indebted for the loan of the specimen. The impression has the same form and position as that already described in the cxample from the Lias of Cheltenham, which is in the British Museum Collection (No. 67929). The specimen is in the centre of a nodule; its dimensions, so far as can be ascertained, are as follows :- diameter of shell $65 \mathrm{~mm}$.; width of umbilicus $31 \mathrm{~mm}$; height of outer whorl $16 \mathrm{~mm}$; ditto at base of body-chamber $13 \mathrm{~mm}$. The last half-whorl is occupied by the body-chamber, the exposed portion of which is almost completely denuded of the test; at its base and on the inner portion of the whorl the outline of the muscular impression can be seen. 'The anterior convex boundary of the impression is $5.5 \mathrm{~mm}$. in advance of the last septum, the width of the impression from the suture of the shell being $2 \mathrm{~mm}$.

There is no trace of the annulus, and the peripheral portion of the fossil is olsscured by matrix.

Agoceras laqueolum, Schloenbach, sp.*-In an example of this species from the Lower Lias of IIarbury, Warwickshire, in the British Museum Collection (No. C. 6619), one of the muscular scars is well displayed. The specimen consists of about three-fourths of a whorl $165 \mathrm{~mm}$. in diameter, and is a natural cast of part of the body-chamber. The base of the body-chamber is complete: it is $24 \mathrm{~mm}$. high ; $30 \mathrm{~mm}$. wide including the ribs, or $29 \mathrm{~mm}$. excluding the ribs. The muscular scar, which is clearly seen at the base of the chamber, is situated partly on the lateral area and partly on the impressed zone (Pl. 20. figs. 3, 4). The faintly-incised line bounding the scar arises from the last septum at a point $105 \mathrm{~mm}$. from the inner edge of the whorl ; then, passing forward for a length of about $9 \mathrm{~mm}$. nearly parallel to the inner edge of the whorl, it turns towards the impressed zone, becomes much more distinct, and erosses the inner edge of the whorl $13 \mathrm{~mm}$. in advance of the last septum; passing on to the impressed zone with a rather broad sweep, it gradually disappears, but the form of the scar is indicated by a difference in colour, the impression being a little darker than the surrounding surface. The impression did not quite reach the middle of the impressed zone; it appears to have been elliptical in form, about $15 \mathrm{~mm}$. long and $11 \mathrm{~mm}$. wide, the larger portion being situated on the impressed zone. On the anterior portion of that part of the scar which is situated on the impressed zone there is an exceedingly faint line, concentric with the anterior border of the scar, which evidently marks a former attachment of the anterior border of the shell-muscle.

Only a very small portion of the other scar is visible; this is on the impressed zone. 'The greater part of the impression is obscured by matrix.

There is no trace of the annulus.

* Palæontogr. vol, xiii. pl. xxvi. f. 1=Caloceras liasicum (d'Orbigny), fide Hyatt, (ien. .1rietidx, p. 139. 
Egoceras Portlockii, Wright.-An example of this species from the Boulder Clay of Ireland (exact locality unknown) was sent to me by Dr. A. H. Foord for determination. It was in a reddish matrix. It is a natural cast of the posterior portion of the bodychamber, showing not quite the complete suture-line at its base, and bearing only fragments of the inner portion of the test. The length of the fragment measured on the periphery is just over $70 \mathrm{~mm}$.; the whorl is much compressed, nearly twice as high as wide; the transverse section of the whorl is elongate-oval, its greatest thickness being at about one-third of the width of the lateral area distant from the suture (of the shell). 'The impressed zone on the inner side of the specimen shows that the indentation by the preceding whorl was very slight, and that the periphery of the preceding whorl was more acutely convex than that of the outer whorl. At the base of the body-chamber the height of the whorl is $33.5 \mathrm{~mm}$, and the greatest thickness about $18 \mathrm{~mm}$. Any indication of the muscular attachment that may be preserved on the surface of the impressed zono is obscured by portions of the test, but on each side of the inner portion of the lateral area of the posterior portion of the cast the impression of this attachment is to be seen. Its anterior houndary commenees at a point on the edge of the impressed zone about $14 \mathrm{~mm}$. in advance of the most anterior portion of the suture-line, i. e. the main or inner branch of the siphonal saddle; it passes outward and backward for a length of about $5 \mathrm{~mm}$., then for a short distance runs nearly parallel to, and at about $5 \mathrm{~mm}$. from, the suture. After passing backward for a distance of nearly $10 \mathrm{~mm}$. from its commencement, the line divides into two principal portions, one being continued almost parallel to, and only slightly approaching, the edge of the impressed zone, the other curving towards, and apparently reaching, the same edge at a distance of $14 \mathrm{~mm}$. from its commencement. A fracture of the specimen prevents the former of the two lines being traced any further. About $1 \mathrm{~mm}$. anterior to the incised line just described, there is a much fainter depressed line which, after extending backward for about $5 \mathrm{~mm}$., nearly parallel to the incised line alrearly described, appears to turn outward towards the periphery, and then quickly to disappear, while posterior to the line already described, and also parallel to it, there are two or three much fainter lines. On the other side of the whorl there are lines corresponding to the principal incised line, and the line about $1 \mathrm{~mm}$. anterior to it, but these can only be traced backward some $6 \mathrm{~mm}$., owing to the crushed state of this side of the specimen.

Near the base of the body-chamber, and slightly on the right side of the median line of the periphery, there is a horseshoe-shaped incised line having its convexity directed forward. Its anterior portion is $12 \mathrm{~mm}$. in advance of the anterior portion of the outer branch of the siphonal (or peripheral) saddle. It is about $6 \mathrm{~mm}$. long, $5 \mathrm{~mm}$. wide in the anterior part, and $3.5 \mathrm{~mm}$. wide in the posterior part. Each limb appears to be continued backward as far as the posterior end of the specimen, which is at about the level of the anterior portion of the outer branch of the peripheral (or siphonal) saddle, as a somewhat irregular, shallow, very faintly-impressed groove or grooves, each being almost parallel to the central line of the periphery. The posterior termination 
of each limb is rather more deeply impressed than the rest. Within this horseshoeshaped impression, and occupying the median line, is a very fine incised line, which extends backward from about $1 \mathrm{~mm}$. posterior to the anterior boundary of the impression for a distance of about $6.5 \mathrm{~mm}$. Doultless this horseshoc-shaped impression had to do with the muscular attachment of the animal to its shell, for it has been observed in other forms, but the present specimen does not cnable us to trace any commection between this impression and the marks of the muscular attachment seen on the inner edge of the whorl.

\section{Sonninia, Bayle.}

Sonninia sp.-In the British Museum Collection there is an example (No. C. 5188) of Sonninia $s p$. from the Inferior Oolite of Yeovil, Somerset, in which the impression of the shell-muscles can be seen (Pl. 20. fig. 12). The test has been renoved from the internal cast of the whole of the body-chamber, and the impression of each shell-muscle is displayed near the base of the chamber. The specimen has the following dimensions :diameter of shell $91 \mathrm{~mm}$; ; width of umbilicus (from suture to suture) $28 \mathrm{~mm}$; ditto (fromi margin to margin) $37 \mathrm{~mm}$; height of outer whorl $36.5 \mathrm{~mm}$.; greatest thickness (almost close to the umbilical margin) 21 $\mathrm{mm}$., excluding thickness of test. The bodychamber oceupies one-hall of the last whorl; at its base the whorl, or more correctly the internal east of the whorl, is $27 \mathrm{~mm}$. high and $1.9 \mathrm{~mm}$. thick. The whorl is subquadrate in section, with nearly parallel sides and well-rlefined inner area, the latter at the base of the boily-chamber being about $6 \mathrm{~mm}$. wide and sloping towards the umbilicus, making an angle of about $140^{\circ}$ with the lateral area. The boundary of the muscular impression is indicated by an incised line which appears on the inner area of the whorl at a point $10.5 \mathrm{~mm}$. anterior to the last septum; it passes outward and backward, just crossing the subangular umbilical margin, on to the lateral area, being at about $6 \mathrm{~mm}$. distant from the suture of the shell, and appears to almost touch the saddle of the last septum that is situated on the subangular umbilical margin. On the area enelosed by this incised line, and conecntric with it, there are several very faint lines, similar to those seen in the impression of the shell-muscles in the recent Nautilus. 'The surface of the cast auterior and also exterior to this incised line bears a number of shallow and irregular indentations, which may have had something to do with the muscular attachment, but the incised line just described appears to have been the impression of the anterior and exterior boundary of the shell-muscle. A similar line and similar adjacent indentations are present on the opposite side of the cast, hut no inclications of the anmulus have been observed in this specimen.

H A R p OCE R A I I d 小, Neumayr, emend. Zittel.

IIEcticocieras, Bonarelli.

Hecticoceras hecticum, lieinecke, sp.-In the British Museum Collection there is an example (No. 22309 a) from the Brown Jura e, Dettingen, Würtemberg, which displays the impression of the muscular attachment on both sides of the body-chamber 
(Pl. 20. figs. 5, 6, 7). It is a natural cast, and has the following dimensions :-Diameter of shell $18.5 \mathrm{~mm}$; ; width of umbilicus $7.5 \mathrm{~mm}$.; height of outer whorl 65 ; greatest thickness $4 \mathrm{~mm}$. At the base of the body-chamber the whorl is $5.5 \mathrm{~mm}$. high and $3.5 \mathrm{~mm}$. thick. The shell is somewhat compressed, the inclusion very slight, and the umbilicus wide and shallow. The body-chamber occupies rather more than one-quarter of the last whorl, its inner (dorsal) edge subtending a chord of $8 \mathrm{~mm}$. on one side and a little less on the other side. From the liactured anterior end of the body-chamber a double feebly-impressed line passes backward at a distance of $1 \mathrm{~mm}$. from the suture (fig. 6) ; then, diverging slightly, the two lines cross the whorl in a rather deep forwardlyconcave curve, their greatest distance from each other being rather more than $1 \mathrm{~mm}$. Approaching each other slightly, but without tonching, they curve forward at the periphery, each forming a submucronate point before passing on to the other side. It is to be noted that these points are not in the median line of the periphery, but slightly on one side (fig. 7). The posterior of the two lines crosses the lateral area about $1 \mathrm{~mm}$. in advance of the anterior portion of the first lateral saddle. On the left side of the anterior end of the body-chamber (fig. 5) the doulble line just described curves slightly towards the periphery, but the opposite side, being a little shorter, does not exhibit this curvature. This double line probably represents a portion of the anterior boundary of the shell-muscle, the two lines on the lateral and peripheral areas indicating the position of the anterior and posterior houndaries respectively of the annulus.

\section{Ecotralstes, Waggen.}

Ecotraustes crenatus, Bruguicre, sp.--'Two examples in the British Muscum Collection (No. 8968), from the Oxfordian of Doubs, France, exhibit what appears to be the muscular impression. Both are natural casts.

One (Pl. 20. fig. 9) of these (No. 8968 b) has the following dimensions (exclusive of the spines on the periphery):-diameter $11 \mathrm{~mm}$.; width of umbilicus $3 \mathrm{~mm}$.; height of outer whorl $5 \mathrm{~mm}$; thickness of ditto $3 \mathrm{~mm}$. At the base of the body-chamber the height of the whorl is $4 \mathrm{~mm}$, and its thickness $2.5 \mathrm{~mm}$. 'The septate part of the shell and the extreme base of the body-chamber are of a reddish-brown colour, while the rest of the body-chamber is of a much darker shade, a dark and very distinct line markingr the division near the base of the hody-chamber. 'This line appears to be the anterior' border of the muscular attachment of the animal. It commences from the suture only a short distance in advance of the last septum, and crosses in a radial direction the inner half of the lateral area until reaching the lateral saddle where it is $0.75 \mathrm{~mm}$. in advance of the suture-line; it then curves slightly backward, making a very shallow curve, until it reaches a point about $1.25 \mathrm{~mm}$. from the median line of the periphery, where it turns somewhat abruptly forward, and reaches the median line of the periphery, $2.25 \mathrm{~mm}$. in advance of the summit of the outer (or peripheral) saddle, thus forming on the periphery a subtriangular projection. A preciscly similar line is seen on the opposite side of the cast, but in this species there does not appear to be any forward prolongation near the 
inner area of the whorl such as has been observed in Distichoceras Bangievi (see below) and Ilecticoceras hecticum (see p. 98).

The other specimen (No. 8968 a) has the following dimensions, exclusive of the peripheral spines, which in this example are comparatively small :-diameter of the shell $11 \mathrm{~mm}$. ; width of umbilicus $2 \mathrm{~mm}$. ; height of outer whorl $5.5 \mathrm{~mm}$. ; thickness of ditto $2.5 \mathrm{~mm}$. At the base of the body-chamber the height of the whorl is $4 \cdot 25 \mathrm{~mm}$. (excluding spines), and the thickness $2.5 \mathrm{~mm}$. The state of preservation of this specimen is quite similar to that of the one just described; the dark line near the base of the body-chamber, which is most probalbly the anterior boundary of the muscular attachment, is very like that in the previous specimen, but is slightly more waved on the latelal area. In this example also there does not appear to be any forward prolongation of the muscular impression on the inner (not impressed) area of the whorl.

The lack of any forward prolongation in this species seems to be confirmed by a specimen (No. $19536 e$ ) in the British Museum Collection, from the Drift of Braunston, Northamptonshire, in which there is an indication of the anterior boundary of the muscular attachment near the suture of the shell, and in this example also it is only a short distance anterior to the last septum.

\section{Distichoceras, Munier-Chalmas.}

Distichoceres Bangieri, d'Orbigny, sp.--In the British Museum Collection there are two examples (No. $5140 a, b$ ) of this species which clearly display the form and position of the muscular attachment of the animal to its shell. The species occurs in the Oxfordian, but the locality of these specimens is not recorded.

In the larger example (No. C. 5110 a) rather more than one-half of the last whorl is occupied by the hody-chamber (Pl. 20. fig. 8). Its dimensions (not including the spines on the edges of the periphery) are:-diameter $17 \mathrm{~mm}$; width of umbilicus $4.5 \mathrm{~mm}$.; height of outer whorl $8 \mathrm{~mm}$. ; greatest thickness (which is at a very short distance from the umbilicus) $4.5 \mathrm{~mm}$. At the base of the body-chamber the height of the whorl is $5 \mathrm{~mm}$., and its thickness $3.5 \mathrm{~mm}$., the transverse section being sublanceolate. Measured along the curve of the inner portion of the lateral area, the anterior boundary of the muscular attachment can be seen as much as $6.5 \mathrm{~mm}$. in advance of the last septum. After passing backward at a distance of $1.75 \mathrm{~mm}$. from, and parallel to, the inner edge of the whorl for a distance of about $5 \mathrm{~mm}$., the boundary then passes outwards in a shallow curve towards the periphery, just before reaching which it turns slightly forward. 'There does not appear to be a definite line at the anterior extremity of the forward prolongation of the impression, but the area included between the boundary of the muscular attachment and the inner edge of the whorl is a little roughened, the surface of the specimen outside this line being smooth and polished. Where the boundary turns outward there are several fine incised concentric lines. It is to be observed that the boundary of the forward prolongation of the muscular attachment does not coincide with the longitudinal groove running along the middle of the lateral area, but is situated between the inner margin of the whorl and this groove. 
The smaller example (No. C. 51.10 b), which exhibits the muscular attachment, has the following dimensions (excluding both the height of the peripheral spines and the inflated terminal portion of the body-chamber) :-diameter $15 \mathrm{~mm}$; width of umbilicus $4 \mathrm{~mm}$; height of outer whorl 6.5 ; thickness $1 \mathrm{~mm}$., the whorl at the base of the bodychamber being $45 \mathrm{~mm}$. high and $3 \mathrm{~mm}$. thick. In this specimen the outer boundary of the forward prolongation of the muscular attachment is slightly more distinct than in the example already described, and appears to be continued backward as a dark (not incised) live into the second lateral lobe on one side of the specimen and on to the second lateral saddle on the opposite side, but at about $2.5 \mathrm{~mm}$. from the last septum it gives off a branch which curves outward towards the periphery, where it is bent slightly forward. The width of the forward prolongation of the impression is $1.5 \mathrm{~mm}$., the most anterior part of the impression being $5 \mathrm{~mm}$. from the last suture-line.

The form and position of the muscular attachment in this species are also exhibited by a specimen* (No. 22267) in the British Museum from the Brown Jura $\zeta$, Beuren, Würtemberg; it agrees with that already described in the example C. $51.10 \%$.

In this species, then, the shell-muscle secms to have been attached to the long flattened surface on the inner area of the body-chamber. The anterior border of the shell-muscle and of the annulus agrees almost precisely with that described and figured by Oppel in his well-known figures of Ammonites $[=$ Oppelia] steraspis from the Lithographic Stone of Solenhofen, Bavaria, a fuct which supports Prof. Zittel's arrangement of the genera Distichoceras and Oppelia in the same subfanily (Oppelince).

\section{STEP II A N OCERATI D A, Neumayr, emend. Zittel.}

\section{Stephanoceras, Waagen.}

Stephanoceras Banksï, J. Sowerby, sp.-There are indications of the muscular attachment of the animal in Sowerby's type-specimen, which forms part of the British Museum Collection. It is a natural internal cast from the Inferior Oolite of the West of England, but the precise locality is not recorded. Its diameter is about $230 \mathrm{~mm}$. (about 9 inches) and its thickness about $150 \mathrm{~mm}$. (or nearly six inches). One-third of the outer whorl is occupied by the body-chamber, the base of which is $50 \mathrm{~mm}$. high and $130 \mathrm{~mm}$. wide. The inner area of the whorl is convex and slopes considerably towards the umbilicus. On the inner area, and arising from the suture of the shell at a point $43 \mathrm{~mm}$. in advance of the last septum, there is a faint impressed line which passes backward and outward across the inner area, crossing the umbilical margin at about $30 \mathrm{~mm}$. posterior to its point of origin and $25 \mathrm{~mm}$. from the suture of the shell. Arising from the suture of the shell, and at a point $20 \mathrm{~mm}$. posterior to the line already described, there is another groove which is rather more distinct and passes backward (more quickly than the anterior line) and outward for rather more than $10 \mathrm{~mm}$., then, with a forwardly-concave curve, passes

* A peculiarity about this specimen is that the chambers are arranged as it were in pairs, a large loculus being succecded by a small loculus. This is certainly the case with the last sixteen chambers. 
to about the middle of the inner area, and then turning backward again it disappears in the broken surface of the specimen. The anterior line probably indicates the position of the anterior boundary of the shell-muscle, and the posterior line possibly the posterior houndary of the same; I think the latter cannot indicate the position of a former attachment of the anterior loundary, for it is not parallel to the anterior line. The other side of the specimen is too batly preserved to show the muscular impression. I have not observed any indications of the position of the annulus in this specimen.

\section{Penispininc'les, Waagen.}

Perisphinctes Achilles, d'Orbigny, sp.-The lateral aspect of the muscular impression in this species is clcarly shown in an example in the British Museum Collection (the smaller of the two specimens, No. 37017) from the White Jura of Randen, near Schaffhausen (Pl. 19. fig. 5). The example is a natural internal cast, almost completely denuded of the test. Its dimensions are :- -diameter of shell $69 \mathrm{~mm}$.; width of umbilicus $28 \mathrm{~mm}$. ; height of outer whorl $24.5 \mathrm{~mm}$; greatest thickness (almost close to the umbilicus) $16 \mathrm{~mm}$. The whorl is much compressed, and not much indented by the preceding whorl ; the body-chamber, measured along the median line of the periphery, is about $80 \mathrm{~mm}$. long. 'The incised line marking the boundary of the muscular impression is plainly visible at the base of the body-chamber. At the inner edge of the whorl it is $5.5 \mathrm{~mm}$. in advance of the most anterior part of the last septum; passing backward and outward for: a short distance, it is then continued backward as an exceedingly faint line as far as the last septum in a direction nealy parallel to the inner edge of the whorl. The width of the impression from the suture of the shell is $2.25 \mathrm{~mm}$., of which only about one-half is visible in the lateral aspect of the shell. The boundary of the anterior portion of the scar is more deeply incised than the rest.

The impression on the other side is similar, but not quite so distinct.

There is no trace of the annulus.

\section{A S P I OCERATII A, Zittel.}

Peltoceras, Waagen.

Peltoceras sp.-The impression of both shell-muscles is well seen on an example of Peltoceras sp. that was found in the Ampthill Clay at Ampthill Tunnel, and that formed part of my late father's collection (Pl. 20. fig. 1). The specimen, a mere fragment of the natural cast of a large shell, consists of the posterior part of the body-chamber; it is about $150 \mathrm{~mm}$. long. It is quadrangular in transrerse section, and at the base of the bodychamber is $73 \mathrm{~mm}$. high, $65 \mathrm{~mm}$. thick (excluding the ribs), and $72 \mathrm{~mm}$. thick (including the ribs). An antiperipheral, antisiphonal, or dorsal aspect of the fragment displays two longitudinally-elongated oval scars, somewhat pointed anteriorly and bounded by a faintly impressed line. 'The outer boundary of each area terminates immediately above the inner' brancli of the lateral saddle, while the imner boundary passes down close to the onter side of the antiperipheral (or antisiphonal) saddle on the same side. The anterior extremity 
of each impression is situated on the edge of the impressed zone, so that about one. third of the width of the impression is on the impressed zone, the other two-thirds being on the inner area of the whorl. The two impressions are nearest together at about half their length; they are here $19 \mathrm{~mm}$. apart, while the posterior extremities of their inner boundaries are $32 \mathrm{~mm}$. apart. The length of each impression (measured from the anterior extremity of the inner branch of the lateral saddle) is about $50 \mathrm{~mm}$; the greatest width being $17 \mathrm{~mm}$. No traces of the annulus have been observed in this specimen. In the middle of the peripheral area, and extending a short distance into the peripheral lobe, there is a broad, faint, longitudinal depression about $25 \mathrm{~mm}$. long and $3.0 \mathrm{~mm}$. wide, slightly wider anteriorly than posteriorly. Possibly this had something to do with the muscular attachment of the animal to its shell. On one side of this there is a narrower, shorter, and less distinct longitudinal depression.

\section{Aspidoceras, Zittel.}

Aspidoceras sp.-Among the specimens which Dr. J. W. Gregory collected from "below Chamgamwe, opposite Mombasa Island," East Africa, there is a fragment of an Aspidoceras which displays the muscular impression ; it is merely the natural cast of the posterior part of the body-chamber, and this is incomplete on one side (Pl. 19. figs. 6, 7). The section of the base is obtusely cordate, and measures about $43 \mathrm{~mm}$. in width and $34 \mathrm{~mm}$. in height. The impression is seen on the inner area of the whorl as a faintlyimpressed line, which, arising from the edge of the impressed zone (corresponding to the suture of the shell) at a point about $15 \mathrm{~mm}$. in advance of the base of the body-chamber, passes outward, describing a curve slightly convex forward, and when at a distance of $9.5 \mathrm{~mm}$. from the edge of the impressed zone passes backward nearly parallel to this edge for a distance of at least $10 \mathrm{~mm}$. It then seems to divide into several very faint grooves which are continued backward nearly to the base of the body-chamber. No indications of the annulus can be seen. Unfortunately the cast is very imperfect on the opposite side.

\section{OS M OCERA T I DE, Zittel.}

Parkinsonia, Bayle.

Parkinsonia Parkinsoni, J. Sowerby, sp.-The muscular impressions are well shown in a well-preserved example of this species in the British Museum Collection (No. 9) from the Inferior Oolite of Bayeux (Calvados), France. Fully two-thirds of the outer whorl are occupied by the body-chamber; the test having been removed from the greater part of this chamber, the internal cast is well displayed. The dimensions of the specimens are:--diameter of shell $243.5 \mathrm{~mm}$; width of umbilicus $58 \mathrm{~mm}$. ; height of outer whorl $49 \mathrm{~mm}$; greatest thickness of ditto $32.5 \mathrm{~mm}$. The body-chamber appears to be fairly complete; its length measured along the median line of the periphery is $287 \mathrm{~mm}$.; and the dimensions of its base are :- height $31.5 \mathrm{~mm}$, greatest thickness (which is at about one-third of the height of the whorl from the inner edge) $22.5 \mathrm{~mm}$. The muscular impression on each side can be seen. At the suture of the shell the 
anterior border, an incised line, is $9.5 \mathrm{~mm}$. in advance of that portion of the latcral saddle of the last suture-line which is close to the umbilical margin; it passes thence outward and backward nearly parallel to the suture and almost as far back as the last septum, when it appears to turn outward and pass over this portion of the lateral saddle as a feebly-depressed rather than an incised line. This last-mentioned portion of the boundary may have been produced by the anterior border of the annulus. The greatest width of the portion of the impression that is visible is $5 \mathrm{~mm}$., and it is confined to the somewhat sloping inner area of the whorl. Its surface is a little roughened, and the impression seems to have occupied the lobe which is situated on the inner area of the whorl. An irregular, waved, depressed line passes over the siphonal lobe on each side of the body-chamber, and this most probably indicates the position of a further portion of the anterior border of the annulus.

\section{Prion OT OP I A Rittel.}

\section{Schlendacilis, Neumayr.}

Schlonbachia Goodhalli, J. Sowerby, sp.--The remains of the muscular attachment are exhibited by an example of this species in the British Museum Collection (No. 16491). The specimen is from the Greensand of Blackdown, Dorset. It consists of a segment of two adjacent whorls, the outer of which exhibits at about its mid-length the basal portion of the body-chamber, which on the left side is entircly denuded of the test. The whorl is earinated, much compressed laterally, and its sides nearly parallel; at the base of the body-chamber it is $80 \mathrm{~mm}$. high and $45 \mathrm{~mm}$. wide or thick, the inner area being concave, sloping towards the umbilicus, and $12 \mathrm{~mm}$. wide. On the left side, on the internal cast of the body-chamber, the anterior boundary of the muscular scar is seen as an incised line arising at the suture of the shell at about $30 \mathrm{~mm}$. in advance of the corresponding portion of the last septum; passing obliquely backward and outward across the inner area, it crosses the umbilical margin at about $22 \mathrm{~mm}$. in advance of the corresponding part of the last septum; it continues outward and backward for a short distance, and then divides; one part passes backward and outward for a very short distance and then disappears; the other passes backward nearly parallel to, and at a distance of $4 \mathrm{~mm}$. from, the umbilical margin, and disappears shortly before reaching the suture-line of the last septum. The branch which passes outward is probably the commencement of the anterior border of the annulus, the other being the outer boundary of the muscular scar. Arising from the suture of the shell, $13 \mathrm{~mm}$. posterior to the line already described, and crossing the inner area nearly parallel to the same line, there is another very feeble groove, which scarcely crosses the umbilical margin before reaching the last suture-line. From the appearance of the inner surface of the piece of the test which fits on to this portion of the specimen, it seems most probable that this feeble groove indicates the position of the posterior boundary of the muscular scar. The opposite side of the whorl is too imperfect to exhibit any trace of the muscular attachment. 
At a point $29 \mathrm{~mm}$. in advance of the small median saddle, the periphery is crossed by an incised line which on the left side passes inward and backward for about $8 \mathrm{~mm}$., then passing backward nearly parallel to, and at a distance of $8 \mathrm{~mm}$., from the median line of the periphery until it meets the external saddle. 'Traces of a precisely similar line can also be seen on the right side. This I believe to have also been part of the anterior boundary of the annulus.

\section{Clymenta, Münster.}

Clymenia undulata, Münster.-W'The muscular impression in the genus Clymenia has been best observed in an example of this species in the British Museum Collection (No. 81826). It is from the Clymenien-Kalk (Upper Devonian) of Schübelhammer, Bavaria (Pl. 20. figs. 13, 14). This specimen, the outer whorl of which is somewhat imperfect, has the following dimensions :-Diameter of shell $48.5 \mathrm{~mm}$; width of umbilicus $20.5 \mathrm{~mm}$; height of outer whorl $16 \mathrm{~mm}$; greatest thickness of ditto $12 \mathrm{~mm}$. Nearly one half of the outer whorl is occupied by the body-chamber, its length, measured along the periphery, being $65 \mathrm{~mm}$. ; its anterior portion is flattened for a distance of nearly $20 \mathrm{~mm}$., the width of the flattened portion being $3 \mathrm{~mm}$. It may be remarked that in this genus the siphuncle is on the inner side of the whorl, and is relatively much larger than in the rest of the Ammonoidea. 'The internal cast of the postcrior part of the body-chamber and of two or three of the succeeding loculi is denuded of the test. The base of the bodychamber is $125 \mathrm{~mm}$. high and $10 \mathrm{~mm}$. thick, the periphery here being quite rounded. One side of the basal portion is well-preserved, but the other is somewhat imporfect. On the well-preserved side (fig. 13) a curved feebly-incised line arises almost close to the suture of the shell and at a distance of $2 \mathrm{~mm}$. from the last septum; passing hackward nearly parallel to the inner half of the lateral portion of the suture-line, it just clears the most anterior portion of the latter and then passes straight on to the periphery, being at the centre of the latter about $2 \mathrm{~mm}$. anterior to the last septum. It appears to cross the periphery without interruption, but unfortunately the line here is somewhat obscured, and it is not impossible that the line here may be bent backward into a very minute $\mathbf{V}$-shaped sinus.

Another feebly-incised line proceeds from the suture of the shell and passes backward almost close to the last septum for some distance into the lateral lobe; then turning forward it meets the anterior line, already described, at the most anterior point of the lateral portion of the suture-line. At a short distance from this junction and a little nearer the periphery, the anterior line gives off a branch which gradually recedes from it and crosses the periphery about $1 \mathrm{~mm}$. posterior to it. At the central portion of the periphery this line, like the anterior one, is somewhat obscured, but appears to cross the periphery without interruption, although it is not impossible that at the middle of the periphery this line may have had a very small $V$-shaped bend forward.

It would seem, therefore, that the shell-muscle occupied the space between the suture of the shell and the outer side of the lateral lobe, and that the annulus extended from 
the outer side of the lateral lobe across the periphery as a narrow band having its greatest width at the centre of the periphery.

Unfortunately, the opposite side of the body-charnber is not sufficiently well-preserved to show the muscular impression.

Near the anterior end of the body-chamber the internal cast exhibits a wide and fairly deep groove, which crosses the lateral area in a curve which is concave forrard, and projects considerably forward near the periphery. The lateral portion of the groove is fully $6 \mathrm{~mm}$. wide, but shallow, while the portion near the periphery is $4 \mathrm{~mm}$. wide and deeper than the rest. The opposite side of the specimen is broken here, and does not show the groove. 'This groove, however, seems to have nothing to do with the muscular attachment of the animal, but is here mentioned for comparison with the groove which has been depicted in some Ammonoids (c. s. Pinacoceras*) as the anterior boundary of the muscle and of the annulus.

\section{GONIA'TI'TES.}

\section{Glyphiocreas, Hyatt.}

Glyphioceras crenistria, J. Phillips, sp.-Among the Goniatites the form of the attachment of the animal to its shell is well seen in an examplet of this species from Bolland, Yorkshile (Pl. 20. figs. 15, 16). It forms part of the British Museum Collection (No. C. 5080). It is a well-preserved example, having the following dimensions:Diameter of shell $43 \mathrm{~mm}$; width of umbilicus about $4.5 \mathrm{~mm}$; height of outer whorl $21.5 \mathrm{~mm}$; thickness of ditto $27.5 \mathrm{~mm}$. The body-chamber occupies five-sixths of the outer whorl, and, being denuded of the test, its internal cast is well displayed. The muscular attachment is so well preserved that it can be traced from tho umbilicus on one side across the whorl to the umbilicus on the other side. As seen in a lateral aspect (fig. 15) the muscular scar is almost confined to the inner area of the whorl, and is depressed (on the internal cast) a little below the surrounding surface. The most anterior portion of its anterior boundary is a little more than $2 \mathrm{~mm}$. in advance of the last septum. Passing backward and outward, this boundary just crosses the umbilical margin and reaches to within about $1 \mathrm{~mm}$. of the septum, when, turning abruptly outward, it is continued as a very fine raised line at this distance from the septum, until passing into the lateral lobe, when it recedes very slightly from the suture-line. It crosses the lobe in an obtuse point $3.75 \mathrm{~mm}$. from the point of the lobe, and, then passing up the other side of the lobe, it gradually approaches the suture-line and, just clearing the pointed external saddle, passes into the external lobe at about $1 \mathrm{~mm}$. from the septum (fig. 16), at the same time separating into two very minutely-waved lines; at $5 \mathrm{~mm}$. from the apex

* Dr. E. v. Mojsisovics, 'Das Gebirge um Hallstatt'; i. pl. xx. figs. $2 \& 3$ (Pinacocer(s insectum); pl. xx. tigs. 8 \& 9 (P. humile).

T 'l'his is the specimen from which the suture-line figured in Cat. Foss. Ceph. British Mruseum, pt. iii. p. 161, fig. 76, was drawn. 
of the external saddle these lines diverge, assume a direction at right angles to the plane of symmetry of the shell, and cross the external lobe with only a very slight $\mathbf{V}$-shaped depression at the median line of the periphery. Nearly at the centre of the periphery there is a small circular pit on the posterior line. On the opposite side of the lobe, at about $1 \mathrm{~mm}$. from the suture-line, these lines turn abruptly forward, approach and coalesce, the resulting line having the same course as that on the opposite side. At the umbilical margin this line passes into the boundary of the muscular scar, which also has the same form as that on the opposite side. At the centre of the periphery and immediately behind the lines already described there is a feebly-depressed double line in the form of a horse-shoe, each side of which passes quite close to the outer side of each half of the small median saddle; the enclosed area is about $2 \mathrm{~mm}$. wide. At a short distance anterior to the raised line already described there is a rather broad shallow groove, which first makes its appearance in the lateral lobe, becomes more distinct all around the external saddle, and disappears in the external lobe. Almost in the median line of the periphery, and slightly in advance of the apex of the external saddle, there is a minute, shallow, oval depression. A fairly-prominent "normal line" extends some 7 or $8 \mathrm{~mm}$. in advance of this depression, whilst the surface of the cast behind this depression and in front of the anterior boundary of the annulus bears numerous fine longitudinal raised lines.

The depressed surface on the inner area of the whorl I regard as a portion of the muscular scar, and the faint line proceeding therefrom across the whorl I consider to be the impression of the annulus. The latter then scems to have been over a portion of its extent merely a line of attachment, but to have been $1 \mathrm{~mm}$. wide on the periphery.

In the present specimen the boundary of the muscular scar cannot be traced on to the inner or dorsal portion (=impressed arca) of the whorl, but this has been partially observed in another example of the same species in the British Museum Collection (the larger of the specimens No. C. 283). The diameter of the shell is $50 \mathrm{~mm}$, the outer whorl (at the end of the septate part of the shell) being about one-half of the diameter. The specimen is entirely septate (Pl. 20. figs. 17, 18), the last septum being the base of the body-chamber. A portion of the test that formed the floor of the body-chamber still adheres to the preceding whorl, and on this the border of the muscular scar can be traced for a short distance. In this example the anterior border of the scar passes on to the floor of the body-chamber at about $3.5 \mathrm{~mm}$. in advance of the last septum; for a short distance it is nearly parallel to the septum, but at about the middle of the lateral saddle it turns towards the septum and seems to disappear; unfortunately the test here has been broken away, and only a few fragments of the test remain on the opposite side of the whorl, so that its direction cannot be definitely traced further. On the floor of the body-chamber (fig. 18) there is also a strong raised line following the lobes and saddles of the last septum, and about $1 \mathrm{~mm}$. in front of the same; near the umbilicus it gradually approaches and then passes into the angle between the septum and the wall of the shell. This seems to have been a line of attachment of the body of the animal; but, so far as can be made out from this example, it does not appear to have been continuous 
with the anterior border of the muscular scar. It may have been the line of attachment of the posterior portion of the body just prior to the formation of a new septum.

Glypirioceras truncatum, J. Phillips, sp.--An example of this species from the Carboniferous Limestone of St. Doulagh's, co. Kildare, Ireland, which has been lent me by Dr. A. H. Foord, F.G.S., also exhibits the anterior boundary of one of the muscular scars very distinctly (Pl. 20. figs. 19). The specimen consists of about five-sixths of a whorl, the whole constituting part of the body-chamber, the base of which is fortunately preserved. Its dimensions are:-diameter $75 \mathrm{~mm}$; height of outer whorl $36 \mathrm{~mm}$; ditto above preceding whorl $20 \mathrm{~mm}$. ; greatest thickness (which is at alout the middle of the lateral area) $27 \mathrm{~mm}$; width of umbilicus $10 \mathrm{~mm}$. On one side of the specimen the anterior boundary of one of the muscular scars is preserved as an impressed line (on the internal cast of the body-chamber), which arises from the suture of the shell at about $4 \mathrm{~mm}$. in advance of the last septum and curves gently outward and backward. It can only be traced for a length of about $6 \mathrm{~mm}$., when it is obscured by the test; at about one-half of this length it is $4.5 \mathrm{~mm}$. from the suture of the shell.

\section{Summary.}

As in the recent Nautilus, so in the Ammonoids, the shell was external and the animal was attached to its shell by means of "shell-muscles" and an "ammulus."

In the Ammonites and such allied forms as Baculites, Hamiles, \&c. the shellmuscles were attached to the dorsal portion of the shell; they froquently either approximated or met each other in the median line of this region; when they did not quite meet they were doubtless united by a more or less narrow band corresponding to the dorsal portion of the annulus in the recent Nautilus.

My observations support the conclusion expressed by Dr. Waagen that the line figured by Oppel on the body-chamber of Ammonites steraspis indicated the position of the anterior boundary of the annulus and of the shell-muscles, the latter being situated, as he supposed, upon the inner or umbilical portion of the lateral area of the whorl. It is, however, not a little strange that in the species figured by Oppel the form of the nuscular attachment differs somewhat considerably from that in the majority of the Ammonites which I have examined. It would seem that another interpretation is necessary for the figures which have subsequently been given purporting to be the remains of the muscular attachment.

In the earlier stages of development and in the general form of the shell as well as in the aperture of certain species, affinities have been recognized between the Ammonoids and the Dibranchiates. From the foregoing it is clear that the Ammonoid animal possessed a muscular attachment quite similar to that of the living Nautilus, the only recent genus of the Tetrabranchiates.

Indications of the muscular attachment of the Ammonoid animal, instead of being rare, seem to be fairly common. There appears to be some ground for believing that its form is in part due to the shape of the transverse section of the whorl and to the 
length of the body-chamber, but I venture to believe that it will prove to be due to other causes, and also afford an inportant character for the purposes of classification. 'Thus, among the forms of muscular attachment described in the present paper, the shell-muscles in Distichoceras and Oppelia seem to have been relatively much longer than those of the other forms herein described; and hence one should expect these two genera to be closely related. This affinity seems to be supported by their other characters, for they have been placed in the same subfamily, viz. the Oppeline *

Not only was the Ammonoid animal, like the Nautilus, at least at some periods, attached to its shell by means of the lobes and saddles of the posterior portion of the body (corresponding to those of the edge of the septum of its shell), but it seems from the foregoing descriptions that it was further provided with an annulus in addition to shell-muscles as in the recent Nautilus. It would appear, therefore, as if the provision of an annulus were an absolute necessity to the animal in addition to the shell-muscles, and most probably Dr. Waagen's explanation of its occurrence is the correct one, viz., that the annulus and shell-muscles served not merely to hold the animal to its shell, but formed also an air-tight band around it, fastening the mantle to the shell.

In conclusion, I desire to express my obligations to those who have in any way assisted me in my observations. To Dr. Woodward I am greatly indebted for valuable suggestions and much kind help, while to Mr. B. B. Woodward I am especially indebted for the advice which he has ever been most willing to give me. My thanks are also due to my colleague Mr. Edgar A. Smith for giving me every facility in the examination of the recent Cephalopoda under his charge. For the loan of specimens I have to thank Mr. F. L. Bradley, Mr. G. F. Harris, and the authorities of the Jermyn Street Museum. To Messrs. Sharman, Newton, and Allen, of that Museum, I am under deep obligations for all their kind help during the examination of the specimens under their charge. To Professor Howes, whose interest in my work has been a source of great encouragement to me, I desire to present my cordial thanks.

\section{EXPLANATION OF THE PLATES.}

The figures are of the natural size unless otherwise stated.

$x$ indicates the last septum.

$\rightarrow$ marks the remains of the muscular attachment.

Plate 17.

Baculites ovatus, Say (p. 77).

Fig. 1. Dorsal aspect of fragment of body-chamber, showing anterior boundaries of muscular scars.

2. Right lateral aspect of same, showing on the left the boundary of the right muscular scar, and on the right the incised line on the ventral area.

* See Prof. Dr. K. A. v. Zittel, 'Grundziige der Paläontologie,' p. 420. 
Fig. 3. Ventral aspect of same, showing incised line on median portion.

4. Right lateral aspect of fragment of another cxample, showing anterior boundary of right muscular scar and of a portion of the ammulus.

Baculites vayina, Forbes (p. 78).

Fig. 5. Dorsal aspect of portion of body-chamber, showing near the base the anterior boundary of the two muscular scars.

\section{Hamites maximus, J. Sowerby (p. 79).}

Fig. 6. Dorsal aspect of body-chamber, showing the two muscular scars near the base.

7. Left lateral aspect of the same.

8. Dorsal aspect of another example.

9. A portion of the same enlarged, showing the two scars, cach bearing near its anterior border a small roughened patch, and also traces of a narrow band comeeting the sears. $\quad \times \frac{2}{1}$.

Crioceras quadratum, n. sp. (pp. $74 \& 79)$.

Fig. 10. Dorsal aspect of a fragment of the body-chamber, exhibiting the two scars.

11. Left lateral aspect of the same.

12. Dorsal aspect of a frament of another cxample in which the anterior boundaries of the two scars nearly meet in the median line.

13. Left lateral aspect of the same.

Ancyloceras Matheronianum, d'Orbigny (p. 80).

Fig. 14. Left lateral aspect, showing portion of anterior boundary of left muscular scar. $\times \frac{1}{4}$.

15. Right lateral aspect of a portion of the same, exhibiting the termination of the anterior boundary of the right muscular scar. $\times \frac{1}{4}$.

16. Dorsal aspect of a portion of the same, showing the anterior boundaries of the two muscular scars, that on the right being much higher than that on the left. $\times \frac{1}{4}$.

Macroscaphites gigas, J. de C. Sowerby, sp. (p. 81).

Fig. 17. Riglit lateral aspect. $\times \frac{1}{4}$.

18. Left lateral aspect of a portion of the same, showing part of the boundary of the two scars. $\times \frac{1}{4}$.

19. Dorsal aspect of a portion of the same, also showing the anterior boundary of the two scars. $\times \frac{1}{4}$.

$$
\text { Scaphites binodosus, A. Roemer (p. 81). }
$$

Fig. 20. Left lateral aspect.

21. Dorsal aspect of a portion of the same, witl part of the body-chamber removed.

Scaplites aqualis, J. Sowerby (p. 82).

Fig. 22. Dorsal aspect of a fragment of the body-chamber. The curved lines at the lower part of the figure are the impressions of the ornaments of the septate part of the shell; the anterior border of the muscular attachment is indicated by the arrow. 


\section{Plate 18.}

Turrilites tuberculatus, Bose (p. 83).

Fig. 1. Lateral aspect, two of the upper whorls exhibiting the siphuncle (si), and the body-chamber showing the muscular attachment. $\times \frac{1}{2}$.

2. Dorsal aspect of body-chamber of same, showing the muscular attachment. $\times \frac{1}{2}$.

Turrilites Mantelli, Sharpe (p. 83).

Fig. 3. Lateral aspect of fragment, the lower whorl of which exhibits a portion of the boundary of the muscular attachment. $\times \frac{2}{3}$.

Turrilites (Heteroceras) polyplocus, Roemer (p. 84).

Fig. 4. Lateral aspect of terminal portion. $\times \frac{1}{2}$.

Oxynoticeras? sp. (p. 85).

Fig. 5. Left lateral aspect of part of an example showing the muscular scar and the annulus. $\quad \times \frac{2}{3}$.

6. Right lateral aspect of same. $\times \frac{2}{3}$.

Amaltheus spinatus, Bruguière, sp. (p. 86).

Fig. 7. Left lateral aspect of imperfect specimen, exhibiting on the inner portion of the whorl (opposite the arrow) the boundary of the muscular scar.

Cardioceras excavatum, J. Sowerby, sp. (pp. 75 \& 86).

Fig. 8. Left lateral aspect, showing the muscular scar and the annulus. $\times \frac{1}{2}$.

Cardisceras aff. excavato, J. Sowerby, sp. (p. 86).

Fig. 9. Left lateral aspect, exhibiting the anterior boundary of the muscular scar on the inner portion of the whorl opposite the arrow, and a linguiform impression on the middle of the lateral area.

10. Dorsal aspect of posterior portion of the body-chamber of the same, showing near the base the course of the anterior boundary of the muscular scar on the dorsal area of the whorl.

Tissotia Ewaldi, v. Buch, sp. (p. 90).

Fig. 11. Left lateral aspect, showing close to the umbilicus (opposite the arrow) one of the muscular scars, and, passing from it towards the periphery, a portion of the anterior boundary of the annulus. $\times \frac{2}{3}$.

\section{Plate 19.}

Cardioceras excavatum, J. Sowerby, sp. (p. 86).

Fig. ]. Right lateral aspect. $\times \frac{2}{3}$.

2. Sagittal section of the natural internal cast of the body-chamber of the same specimen, showing anterior boundary of muscular scar on dorsal portion of whorl. $\times \frac{2}{3}$.

$$
\text { Cardioceras sp. (p. 89). }
$$

Fig. 3. Left lateral aspect, showing anterior boundary of scar and of annulus. $\times \frac{2}{1}$.

4. Ventral view of the same, exhibiting the impression on the central portion of that area.

SECOND SERTES. - ZOOLOGY, VOL. VII. 
Perisphinctes Achilles, d'Orbigny, sp. (p. 102).

Fig. 5. Luft lateral aspect. The boundary of the muscular scar is seen on the inner portion of the outer whorl opposite the small arrow.

Aspidoceras sp. (p. 103).

Fig. 6. Dorsal aspect of a fragment of the body-chamber.

7. Right lateral aspect of the same.

Arietites obtusus, J. Sowerby, sp. (p. 93).

Pig. 8. Left lateral aspect of a portion of a specimen, showing the muscular scar on the inner portion of the outer whorl opposite the arrow.

9. Right lateral aspect of the same.

10. Ventral aspect of the same, showing the linguiform impression on the central portion, and anterior to it an $f$-shaped incised line in the depression on each side of the keel.

Lytoceras fimbriatum, J. Sowerby, sp. (p. 91).

Fig. 11. Jorsal aspect of the posterior portion of the body-chamber, exhibiting the left and a portion of the right muscular scar.

12. Tueft lateral aspect of the same.

Lytoceras cornucopia, Young \& Bird, sp. (p. 91).

lig. 13. Dorsal aspect of the posterior portion of the body-chamber.

14. Right lateral aspect of the same.

15. Right lateral aspect of another specimen, showing the small oval scar on the inner part of the outer whorl opposite the arrow.

16. Portion of same enlarged, showing muscular scar. $\times \stackrel{2}{1}$.

1\%. Veutral aspect of portion of same enlarged, exhibiting the linguiform impression. $\times \ddot{I}$.

\section{Pláte 20.}

Peltoceras sp. (p. 102).

Fig. 1. Dorsal aspect of fragment, showing the two elongated muscular scars. $\quad \times \frac{1}{2}$.

Agoceras capricornum, Schloth., sp. (p. 95).

lig. 2. Right lateral aspect. The muscular scar is the small white pateh on the inner portion of the outer whorl opposite the arrow.

Agoceras laqueolum, Schloenbach, sp. (p. 96).

Fig. 3. Dorsal aspect of fragment of body-chamber, showing the left muscular scar and part of the right.

4. Left lateral aspect of the same. 
Hecticoceras hecticun, Reinecke, sp. (p. 98).

Fig. 5. Left lateral aspect. $\times \frac{3}{3}$.

6. Right lateral aspect of same. $\times \frac{3}{2}$.

7. Ventral aspect of portion of same. $\times \frac{3}{2}$.

Distichoceras Baugieri, d'Orbigny, sp. (p. 100).

Fig. 8. Right lateral aspect. $\times \frac{2}{1}$.

Ecotraustes crenatus, Bruguière, sp. (p. 99).

Fig. 9. Right lateral aspect. $\times \frac{2}{1}$.

Arietites raricostatus, Zieten, sp. (p. 94).

Fig. 10. Left lateral aspect of entire specimen.

11. Dorsal aspect of the portion $a b$, which is a natural internal cast of part of the body-chamber, showing at the base the remains of the two muscular scars.

Sonninia sp. (p. 98).

Fig. 12. Left lateral aspect, exhibiting the muscular scar on the inner portion of the outer whorl opposite the arrow, and also the adjacent indentations.

Clymenia undulata, Münster (p. 105.)

Fig. 13. Right lateral aspect.

14. Peripheral aspect of the same.

Glyphioceras crenistria, J. Phillips, sp. (p. 106).

Fig. 15. Left lateral aspect. The fine white line opposite the arrow is the boundary of the annulus; the subtriangular patch into which it passes near the umbilicus is the left muscular scar, the black line posterior to it is the edge of the last septum, the lighter portion near it being the broken edge of the test.

16. Front view of the same, the arrow pointing to the line indicating the annulus.

17. Left lateral aspect of another example. The anterior septum is the base of the body-chamber. The muscular scar is indicated by the light patch (opposite the arrow) on the piece of the test, one layer of which is part of the floor of the body-chamber.

18. View of same from above; the raised line on the piece of test which is part of the floor of the body-chamber being indicated by the white line marked $a$.

Glyphioceras truncatum, J. Phillips, sp. (p. 108).

Fig. 19. Left lateral aspect. $\times \frac{2}{3}$. 


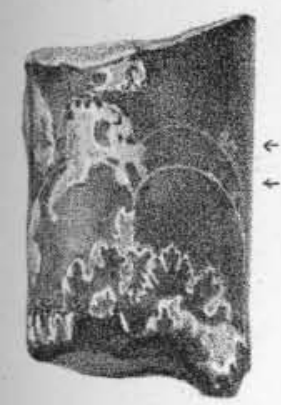

1.

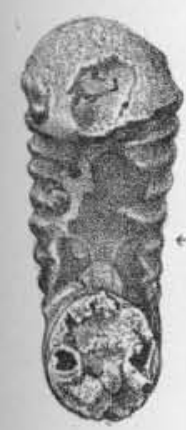

8

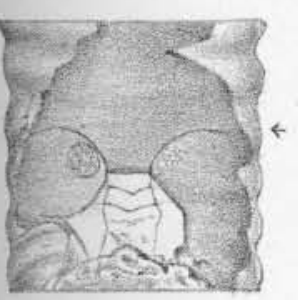

9

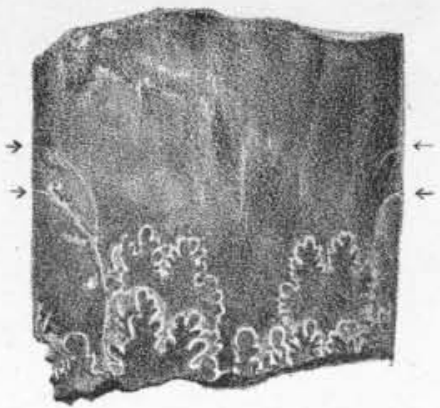

2



4
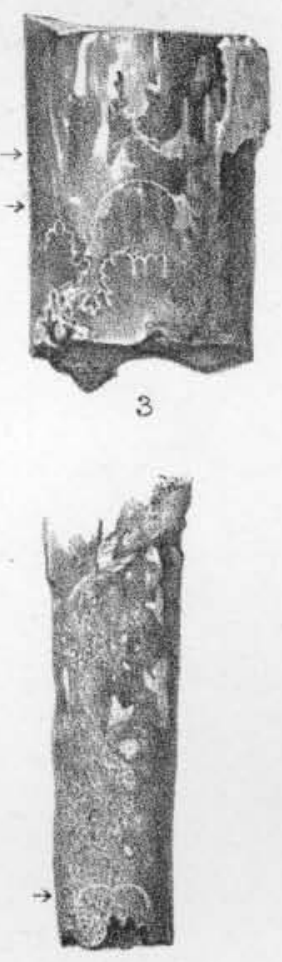

5

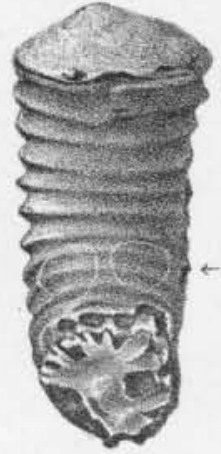

6

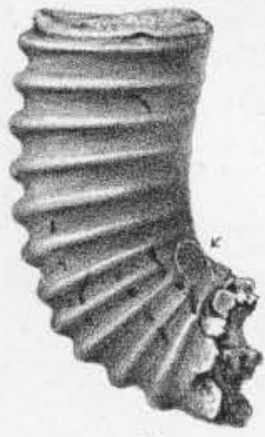

7

21
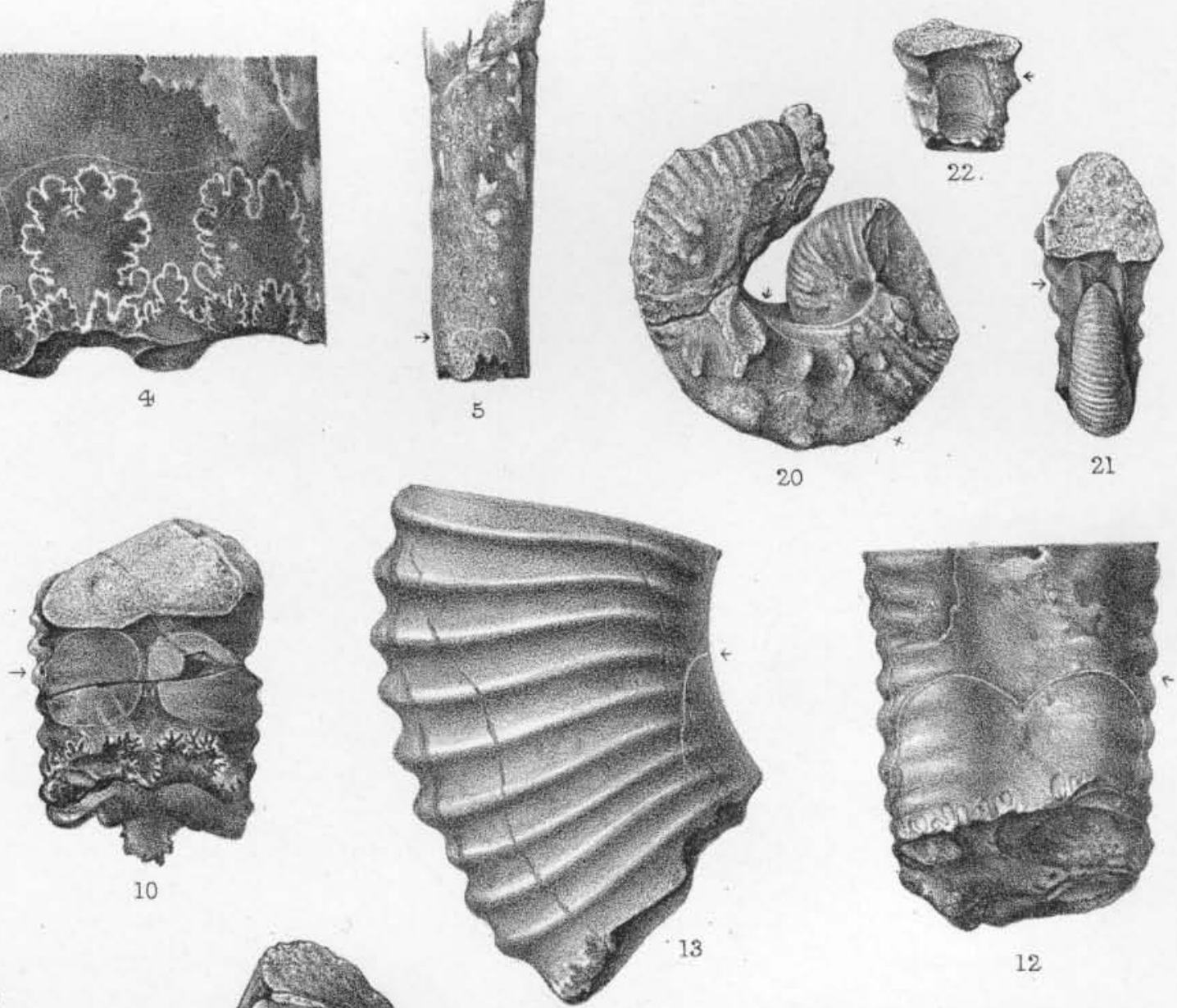

12

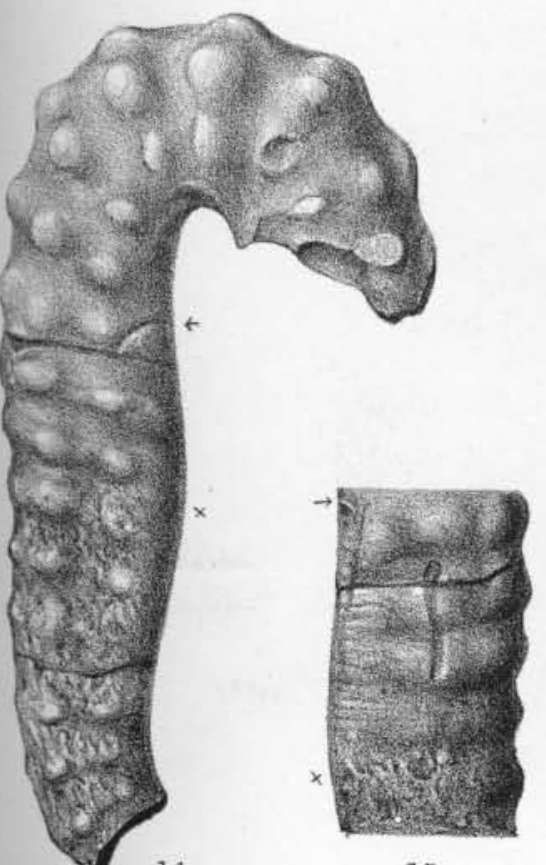

14

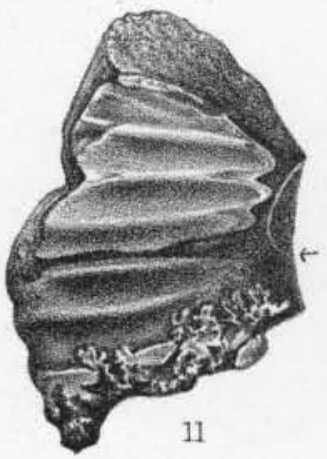

19

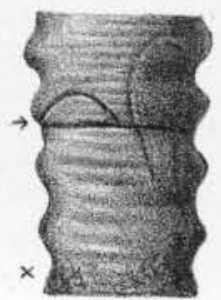

16

J.Green del et lith.

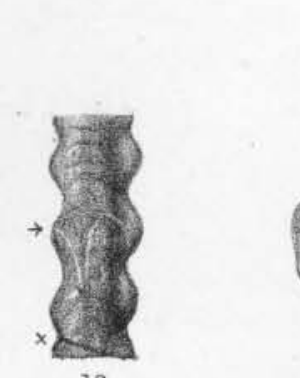

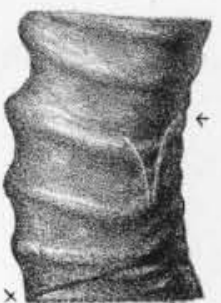

18

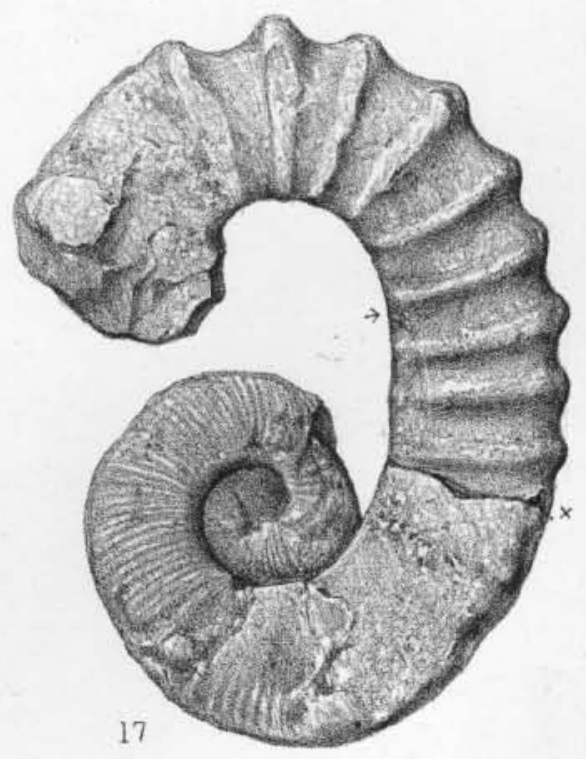

Mintern Bros.imp 

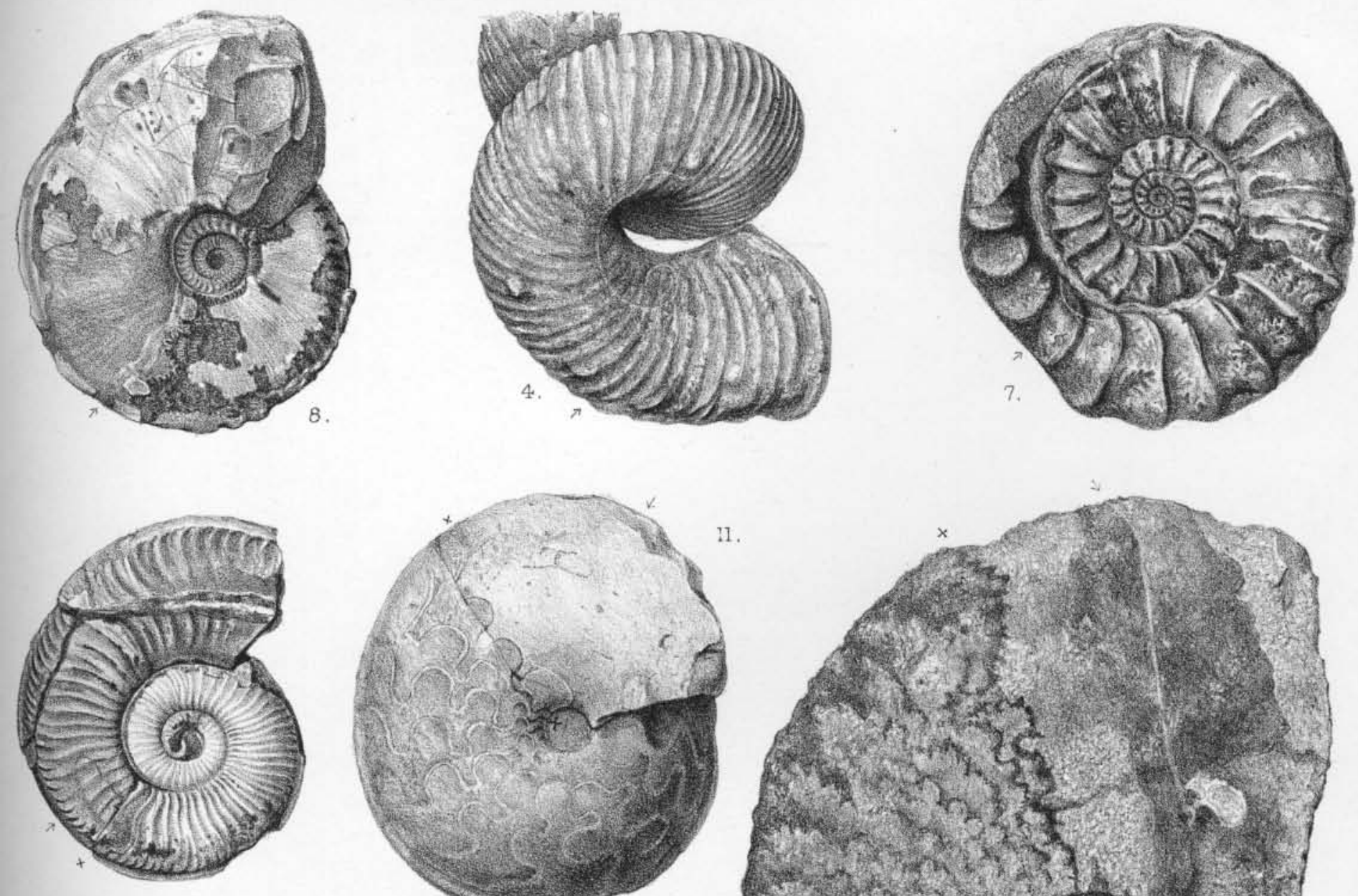

9.
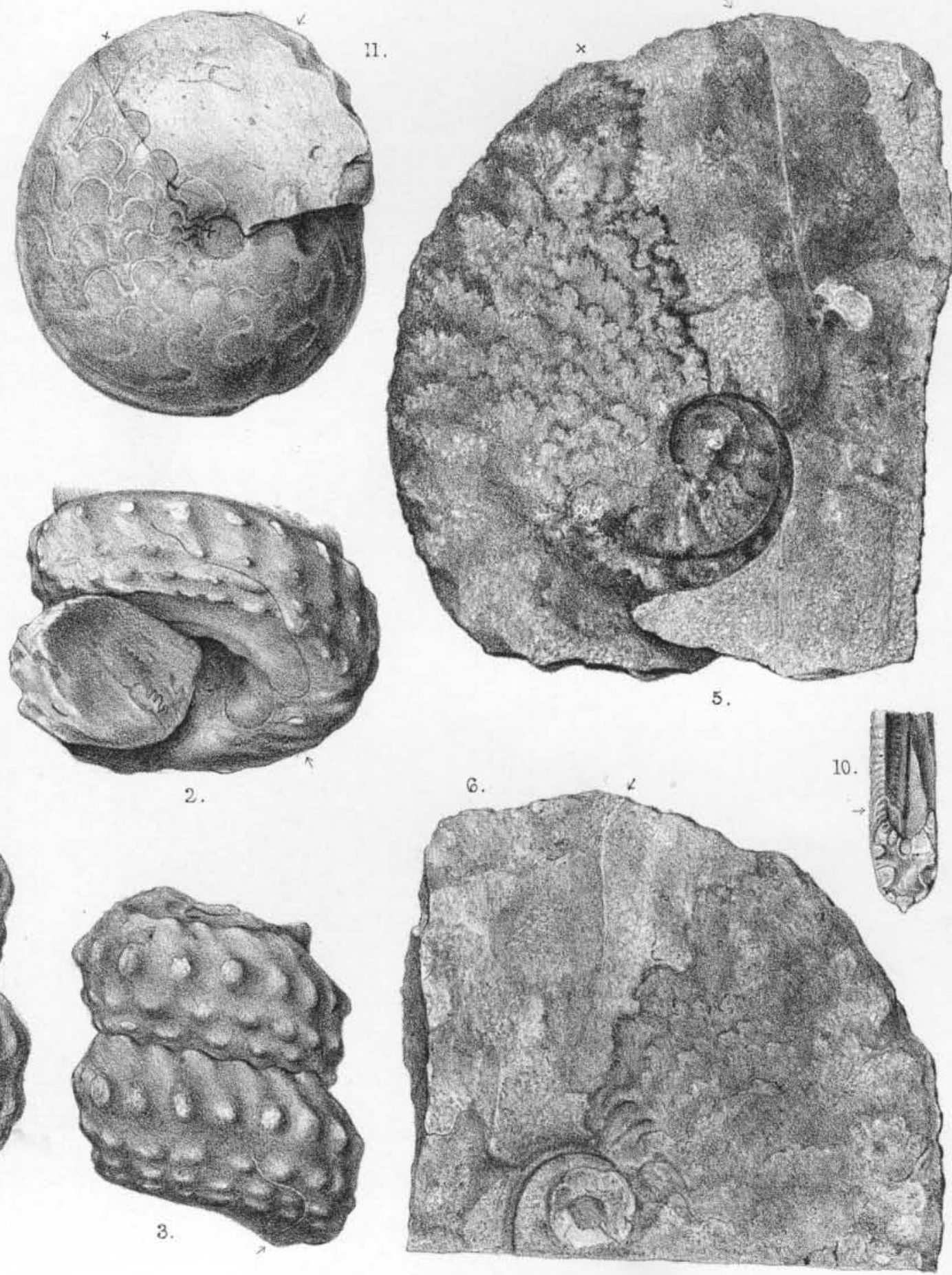


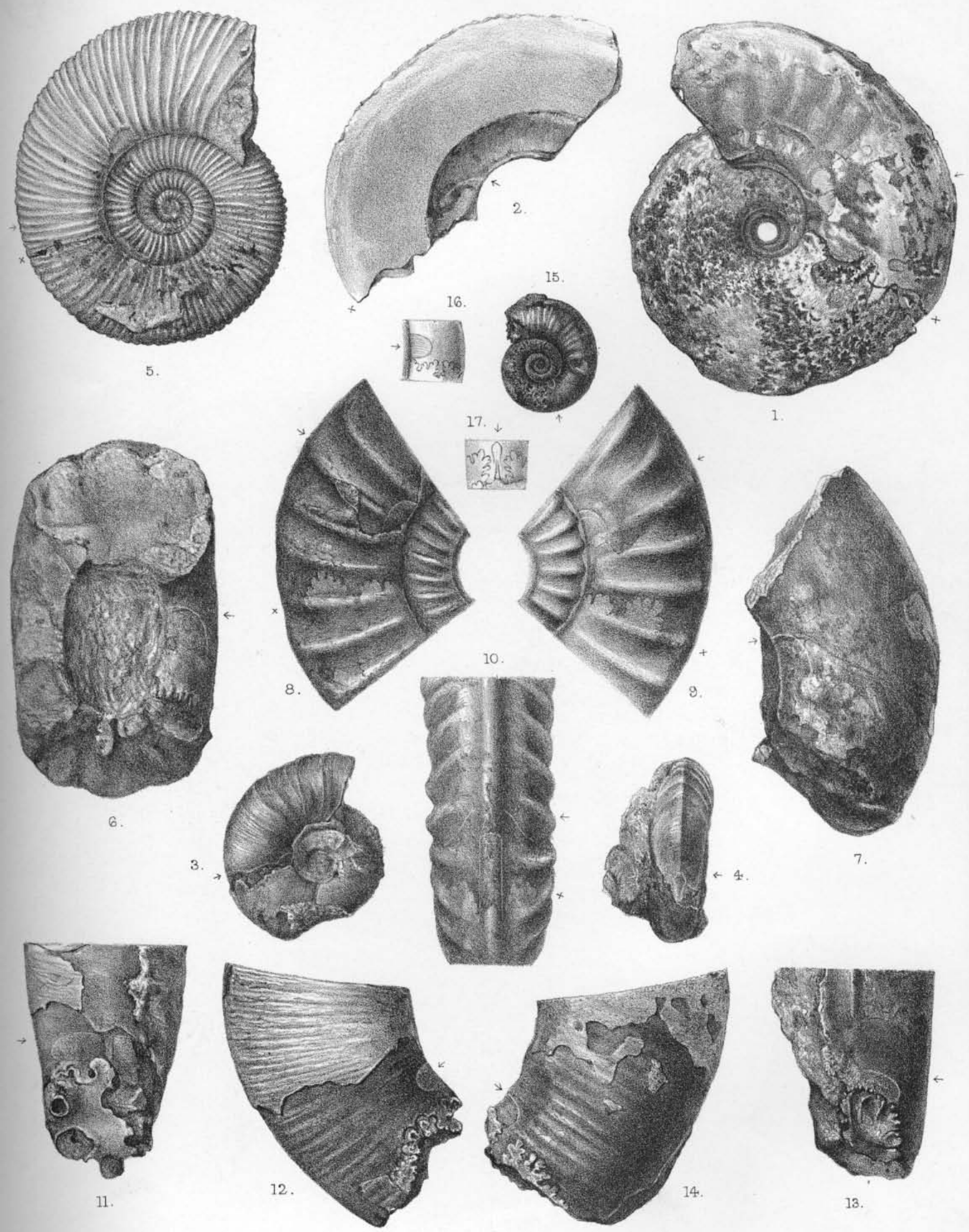


Trans Linn Soc. Zool. Ser 2.Vol. VII. Pl. 20.
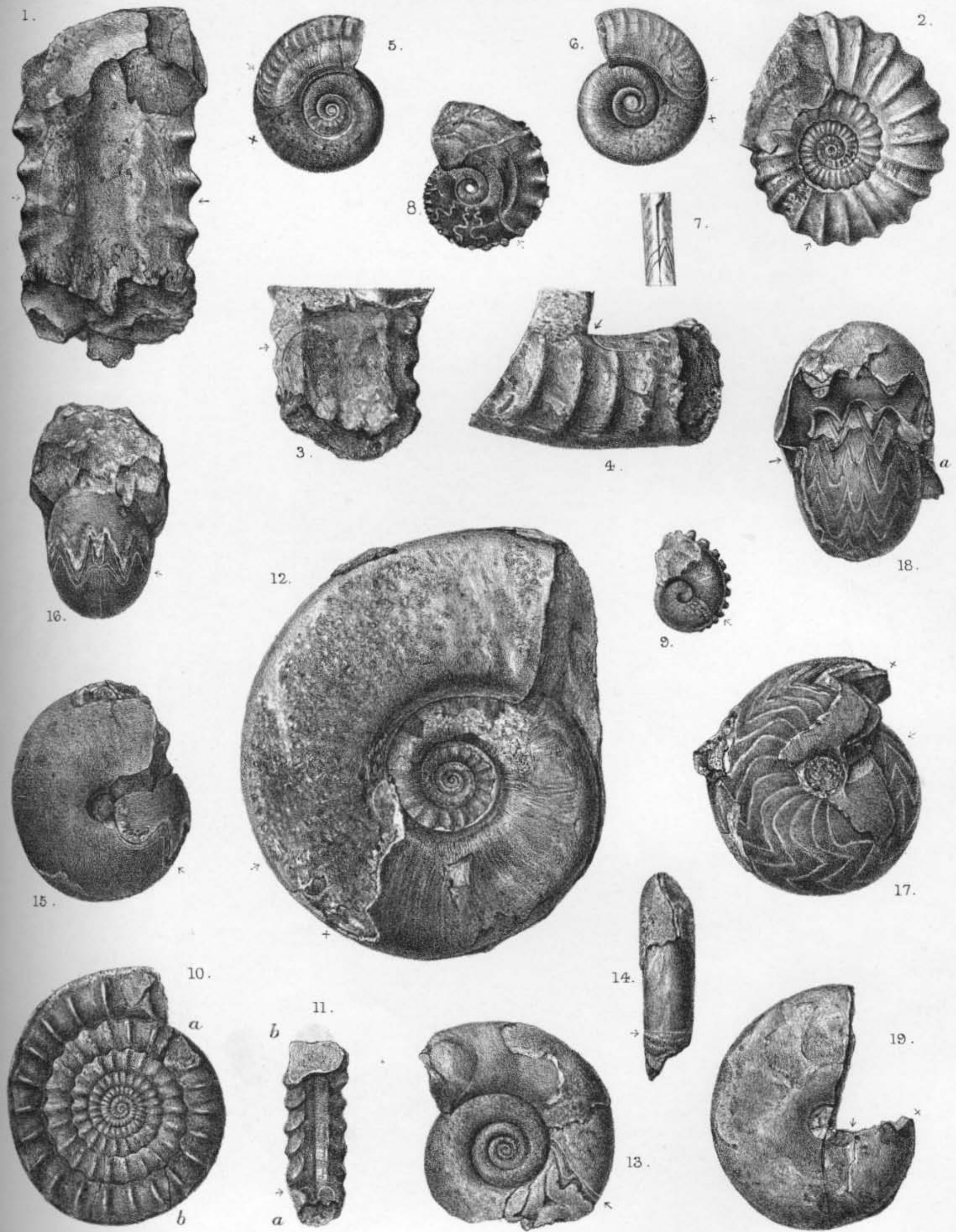

9.

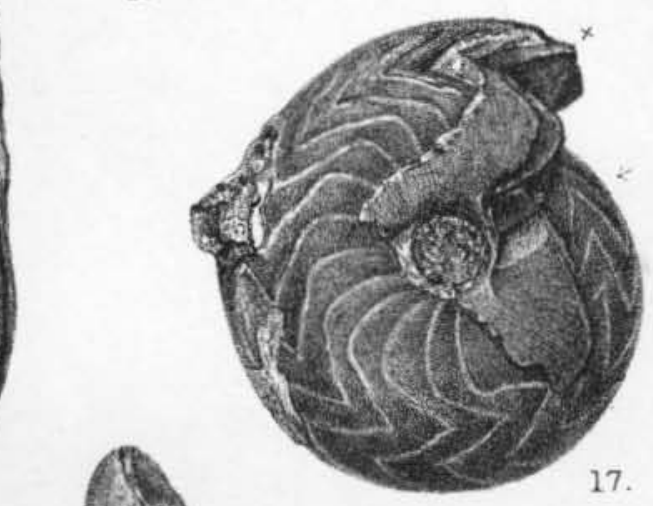

